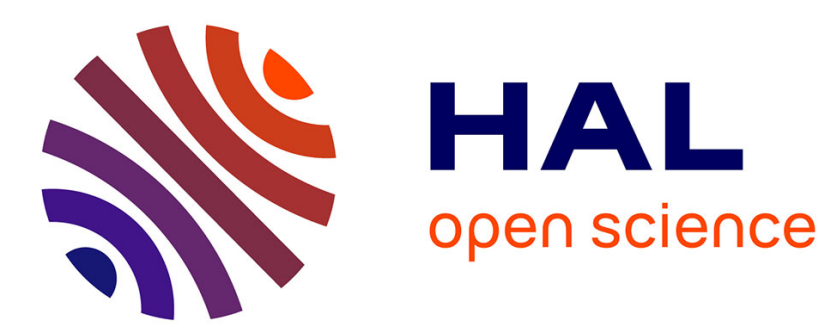

\title{
Agroecological practices for sustainable agriculture. A review
}

\author{
Alexander Wezel, Marion Casagrande, Florian Celette, Jean-François Vian, \\ Aurélie Ferrer, Joséphine Peigné
}

\section{- To cite this version:}

Alexander Wezel, Marion Casagrande, Florian Celette, Jean-François Vian, Aurélie Ferrer, et al.. Agroecological practices for sustainable agriculture. A review. Agronomy for Sustainable Development, 2014, 34 (1), pp.1-20. 10.1007/s13593-013-0180-7 . hal-01234800

\author{
HAL Id: hal-01234800 \\ https://hal.science/hal-01234800
}

Submitted on 27 Nov 2015

HAL is a multi-disciplinary open access archive for the deposit and dissemination of scientific research documents, whether they are published or not. The documents may come from teaching and research institutions in France or abroad, or from public or private research centers.
L'archive ouverte pluridisciplinaire HAL, est destinée au dépôt et à la diffusion de documents scientifiques de niveau recherche, publiés ou non, émanant des établissements d'enseignement et de recherche français ou étrangers, des laboratoires publics ou privés. 


\section{Agroecological practices for sustainable agriculture. A review}

\author{
Alexander Wezel • Marion Casagrande • Florian Celette • \\ Jean-François Vian • Aurélie Ferrer • Joséphine Peigné
}

Accepted: 6 September 2013 / Published online: 27 September 2013

(C) INRA and Springer-Verlag France 2013

\begin{abstract}
The forecasted 9.1 billion population in 2050 will require an increase in food production for an additional two billion people. There is thus an active debate on new farming practices that could produce more food in a sustainable way. Here, we list agroecological cropping practices in temperate areas. We classify practices according to efficiency, substitution, and redesign. We analyse their advantages and drawbacks with emphasis on diversification. We evaluate the potential use of the practices for future agriculture. Our major findings are: (1) we distinguish 15 categories of agroecological practices ( 7 practices involve increasing efficiency or substitution, and 8 practices need a redesign often based on diversification). (2) The following agroecological practices are so far poorly integrated in actual agriculture: biofertilisers; natural pesticides; crop choice and rotations; intercropping and relay intercropping; agroforestry with timber, fruit, or nut trees; allelopathic plants; direct seeding into living cover crops or mulch; and integration of semi-natural landscape elements at field and farm or their management at landscape scale. These agroecological practices have only a moderate potential to be broadly implemented in the next decade. (3) By contrast, the following practices are already well integrated: organic fertilisation, split fertilisation, reduced tillage, drip irrigation, biological pest control, and cultivar choice.
\end{abstract}

Keywords Agroecology · Diversification of cropping system $\cdot$ Efficiency increase $\cdot$ Substitution $\cdot$ Systems redesign

\footnotetext{
A. Wezel $(\bowtie) \cdot$ M. Casagrande $\cdot$ F. Celette $\cdot$ J.-F. Vian · A. Ferrer $\cdot$ J. Peigné Department of Agroecology and Environment, ISARA Lyon (member of the University of Lyon), 23 rue Jean Baldassini, 69364 Lyon cedex 07, France

e-mail: awezel@isara.fr
}

Contents

1. Introduction. . . . . . . . . . . . . . . . . . . .

2. Definition of agroecological cropping practices and analytical framework. .................... 3

3. Efficiency increase and substitution agroecological practices......................... 3

3.1. Crop choice, crop spatial distribution and crop temporal successions. . . . . . . . . . . . 7

3.2. Crop fertilisation management. . . . . . . . . .8

3.3. Crop irrigation. . . . . . . . . . . . . . . .9

3.4. Weed, pest and disease management. . . . . . . 99

4. Redesign agroecological practices. ........... 9

4.1. Crop choice, crop spatial distribution, and crop temporal succession. ................ 9

4.1.1. Cover crop/green manure. . . . . . . . . . .9

4.1.2. Crop temporal successions. . ......... 10

4.1.3. Crop spatial distribution-intercropping and agroforestry................. 10

4.2. Weed, pest, and disease management—allelopathic plants. . . . . . . . . . . . . . . . 11

4.3. Tillage management. .............. 12

4.4. Management of landscape elements. .........12

5. Promising agroecological practices. .......... 13

5.1. Scales of application, system change. ....... 13

5.2. Integration in today's agriculture and promising agroecological practices. ...............14

6. Outlook beyond agroecological practices. . . . . . 16

7. Conclusion. . . . . . . . . . . . . . . . . 16

8. References. ..................... 16

\section{Introduction}

The forecasted increase in world population of up to 9.1 billion in 2050 (United Nations 2009) will require a major effort to increase food production for an additional two billion 
people compared to today. Disregarding allocation problems, overproduction and food waste in some world regions, this would mean that about $30 \%$ more food is needed at the global level. Thus, world agriculture is facing major challenges in producing this additional food. In addition, there has been an increasing demand in the last decades to not only produce larger quantities, but to also achieve development towards sustainable agriculture where production is simultaneously environmental friendly, socially fair, and economically beneficial. It will be necessary to develop agricultural food production practices for all types of agriculture, be it conventional, integrated, or organic agriculture.

There is a strongly contrasting, on-going debate around the most appropriate agricultural production practices with which to reach the goal of higher, and also sustainable food production (e.g. Borlaug 2000; Huang et al. 2002; McNeely and Scherr 2003; Médiène et al. 2011; Perfecto and Vandermeer 2010; Phipps and Park 2002; Prasifka et al. 2009; Swaminathan 2007; Tilman et al. 2002). Agricultural options range from high technology-based practices to ecology-based practices. On the one hand, precision farming (Srinivasan 2006) or use of genetically modified crops (e.g. Huang et al. 2002; Phipps and Park 2002) could help match the future food demand. On the other hand, practices such as natural biological control of pests (Fig. 1), such as integrating natural landscape elements into agricultural landscapes (Fig. 2) in order to decrease pesticide use (e.g. Altieri and Nicholls 2004; Gurr et al. 2004) or no or reduced tillage, that increase soil biota activity and improve soil fertility (Holland 2004), are other possible options.

Practices such as organic crop fertilisation, crop rotations, or biological pest control are well-known agricultural

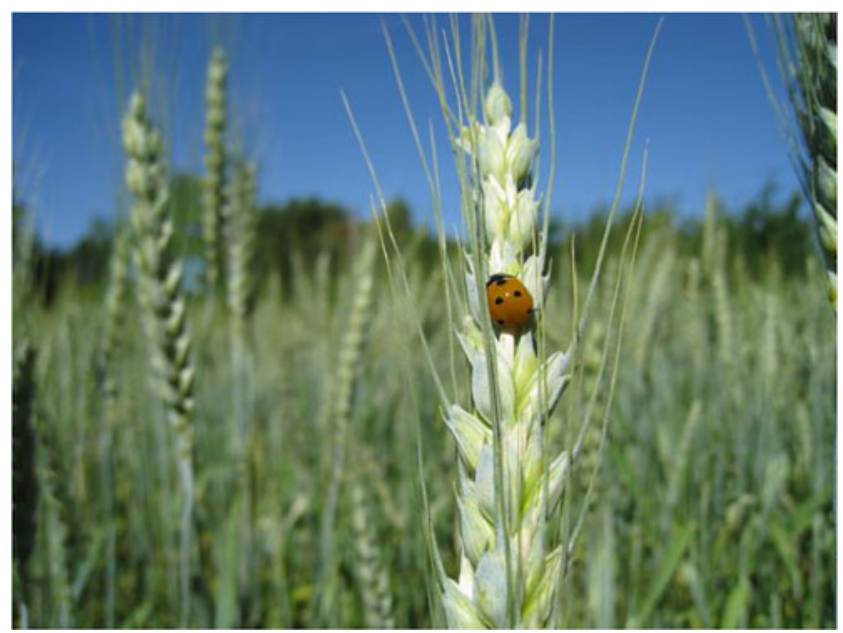

Fig. 1 Conservation biological control: preservation or creation of habitats near fields or in the larger landscape for reproduction, over-wintering, or shelter during different phases of life cycle of beneficial insects which then can control pests. The present photo shows a ladybird beetles, a natural predator of aphids, on organic wheat in southeastern France (photo by A. Wezel)

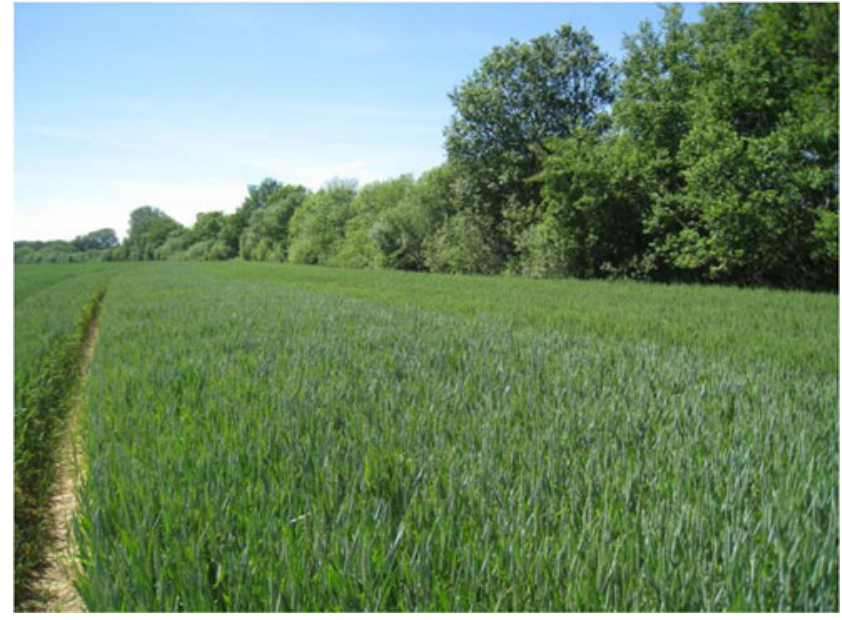

Fig. 2 Landscape elements surrounding a cereal field, southeastern France. Woody landscape elements for example can have different functions such as protection against wind and water erosion, habitats for beneficial insects and pollinators, production of timber and firewood, ecological corridors in agricultural landscapes, and biodiversity conservation (photo by A. Wezel)

practices that have been widely used for a long time. However, during the last two decades, they have been increasingly described as agroecological practices (e.g. Altieri 1995; Arrignon 1987). The term "agroecological practices" emerged in the 1980s within the development of agroecology (Wezel et al. 2009). Today, agroecology as a practice is one of three major currents or interpretations of agroecology, the others being a scientific discipline and a movement. Examples of agroecological practices are already mentioned in literature, e.g. cover crops, green manure, intercropping, agroforestry, biological control, resource and biodiversity conservation practices, or livestock integration (Altieri 1995, 2002; Arrignon 1987; Gliessman 1997; Wojtkowski 2006). Nevertheless, we are still lacking to specify the characteristics that identify them as agroecological practices. What are their advantages and constraints, and which potential do they have in the future? For example, agroforestry in developing countries, with the integration of trees into cropland, is not beneficial per se when crop yields are strongly decreasing due to loss of cropland or competition for light, nutrients, and water with trees, therefore generating a risk for smallholder family survival. Moreover, what are the more recently developed practices that could be promising in developing a more sustainable agricultural production, and could be considered as innovative agroecological practices? An innovative practice can be something completely new, but also a practice based on age-old principles or techniques that have been little studied (Uphoff 2002) and which are newly adapted, thus creating a novelty for improvement. The origins of innovative practices can be quite different. They may be something new (discovered accidentally), something purposefully sought through experimentation (such as different potential practices), or they 
may be the outcome of a radical change in thinking, or approach, to establish a new system (e.g. biodynamic agriculture), thus creating innovations for the practical implementation of the new system.

The aim of this review is to define agroecological practices and present them with their constraints, advantages and their potential in a concise manner. So far, agroecological practices have been presented in books or papers, some with extensive literature, but either only focusing on one practice or on only some of them, and in most cases only generally calling them agroecological practices without defining what qualifies them as such. Also, a summarised evaluation of the potential of a large set of agroecological practices has, to our knowledge, not yet be made in a review paper. A final point is that evaluating agroecological practices has been to a larger extent done for practices which are mainly used in the tropics and subtropics, but so far this has only been done to a limited extent focusing on temperate areas.

Therefore, in this paper, we define and present agroecological cropping practices of crop-based farming systems in temperate areas in analysing their potential and constraints, and in classifying them into efficiency increase, substitution, and redesign practices. We also analyse which practices are based on diversification of systems. In addition, we carry out a detailed analysis of more recently developed agroecological practices by evaluating their potential and constraints to contribute to the different goals of sustainable agriculture: to provide sufficient food for a growing world population not to be at the detriment or risk to the environment and to assure economic viability for farmers.

\section{Definition of agroecological cropping practices and analytical framework}

In our understanding, agroecological practices are agricultural practices aiming to produce significant amounts of food, which valorise in the best way ecological processes and ecosystem services in integrating them as fundamental elements in the development of the practices, and not simply relying on ordinary techniques, such as chemical fertiliser and synthetic pesticide application or technological solutions, such as genetically modified organisms. Indeed, agroecological practices contribute to improving the sustainability of agroecosystems while being based on various ecological processes and ecosystem services such as nutrient cycling, biological $\mathrm{N}$ fixation, natural regulation of pests, soil and water conservation, biodiversity conservation, and carbon sequestration. Some of these practices have already been applied in varying degrees in different regions of the world for years or decades, while others were more recently developed and still have a limited rate of application.
In this review, we present agroecological practices in temperate areas, and classify them according to the analytical framework of Hill and MacRae (1995). It describes an agricultural transition towards sustainable agriculture by defining three (usually) consecutive stages: efficiency increase, substitution, and redesign. Nevertheless, some farmers enter the third stage directly when dramatically changing their cropping systems, e.g. moving to no tillage systems or agroforestry systems.

Efficiency increase refers to practices that reduce input consumption (e.g. water, pesticides, and fertilisers) and improve crop productivity. Substitution practices refer to the substitution of an input or a practice (e.g. replacing chemical pesticides by natural pesticides). Finally, redesign refers to the change of the whole cropping or even farming system. Note that one practice could correspond to one or more categories of such a framework (Table 1).

Furthermore, we distinguish between practices that are either related to crop management or the management of landscape elements. In the case of crop management practices, we distinguish different types: (1) practices addressing crop choice, crop spatial distribution, and crop temporal successions; (2) tillage practices; (3) fertilisation practices; (4) irrigation practices; and (5) weed, pest, and disease management practices. In the case of landscape element management, we distinguish between practices at the field/farm level and landscape level. In Fig. 3, we summarise the categories of practices and show their scales of application.

In developing agroecological practices, the question of diversification is inevitable, as these practices are based on ecological processes and provision of ecosystem services. In the last decade, a growing number of scientists have claimed that species diversity has to be (re)integrated into cropping systems for a host of reasons, e.g. higher agroecosystem resilience to perturbation (Jackson et al. 2007; Loreau 2000; Malézieux et al. 2009; Tilman et al. 2006; Vandermeer et al. 1998, 2002), decreased pest outbreaks (including weeds), or biodiversity conservation (e.g. Médiène et al. 2011). Diversification refers to integration of more diverse cultivars, crops or intercrops into the cropping systems, or valorising natural biodiversity for agricultural purposes such as conservation biological control. Thus, we also specify in Table 1 if the presented practices lead to system diversification.

\section{Efficiency increase and substitution agroecological practices}

Efficiency increase refers to practices that reduce input consumption (e.g. water, pesticides, and fertilisers) and improve crop productivity. Substitution practices refer to the substitution of an input or a practice, e.g. replacing chemical pesticides by natural pesticides. 
A. Wezel et al.

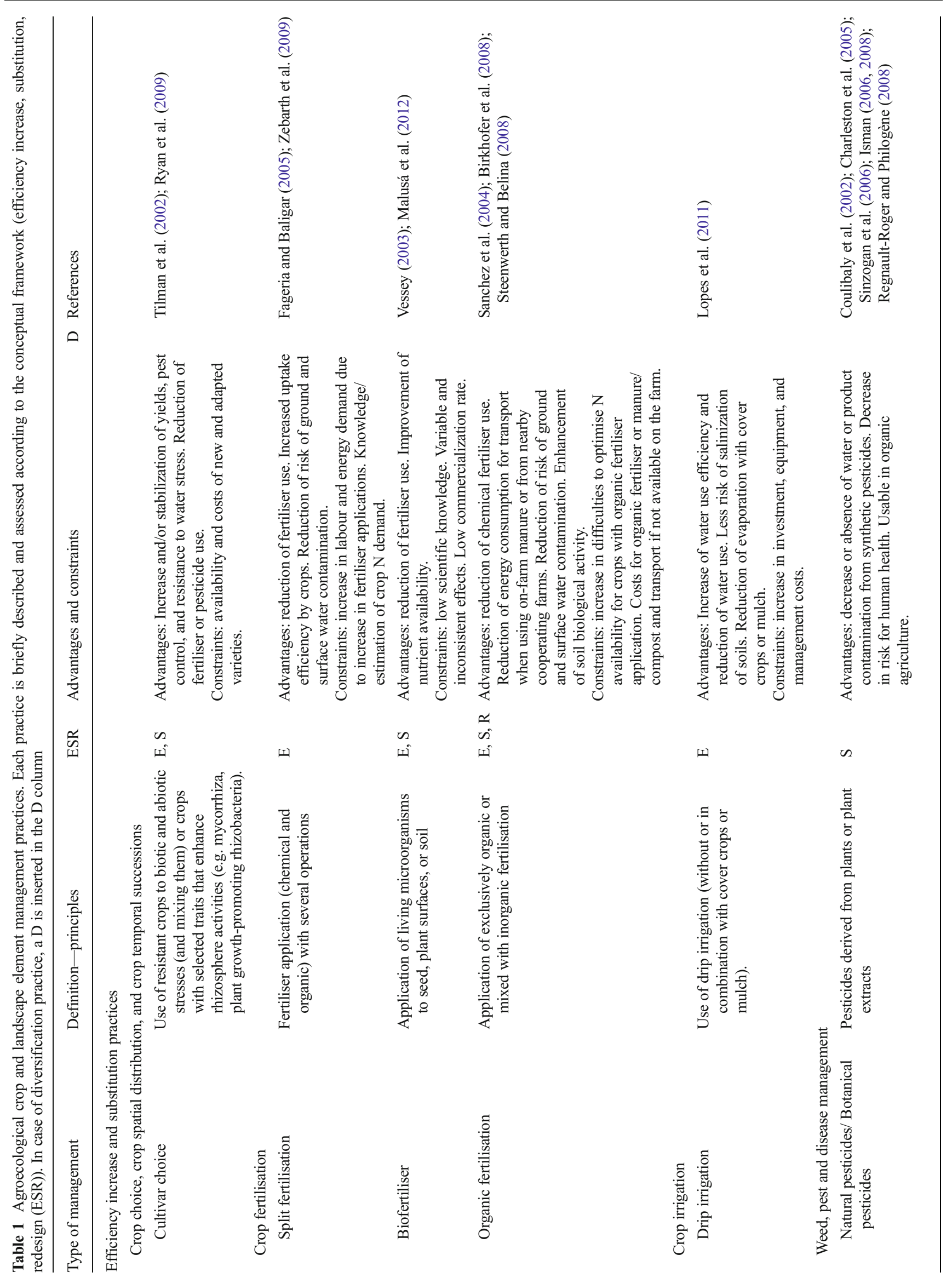




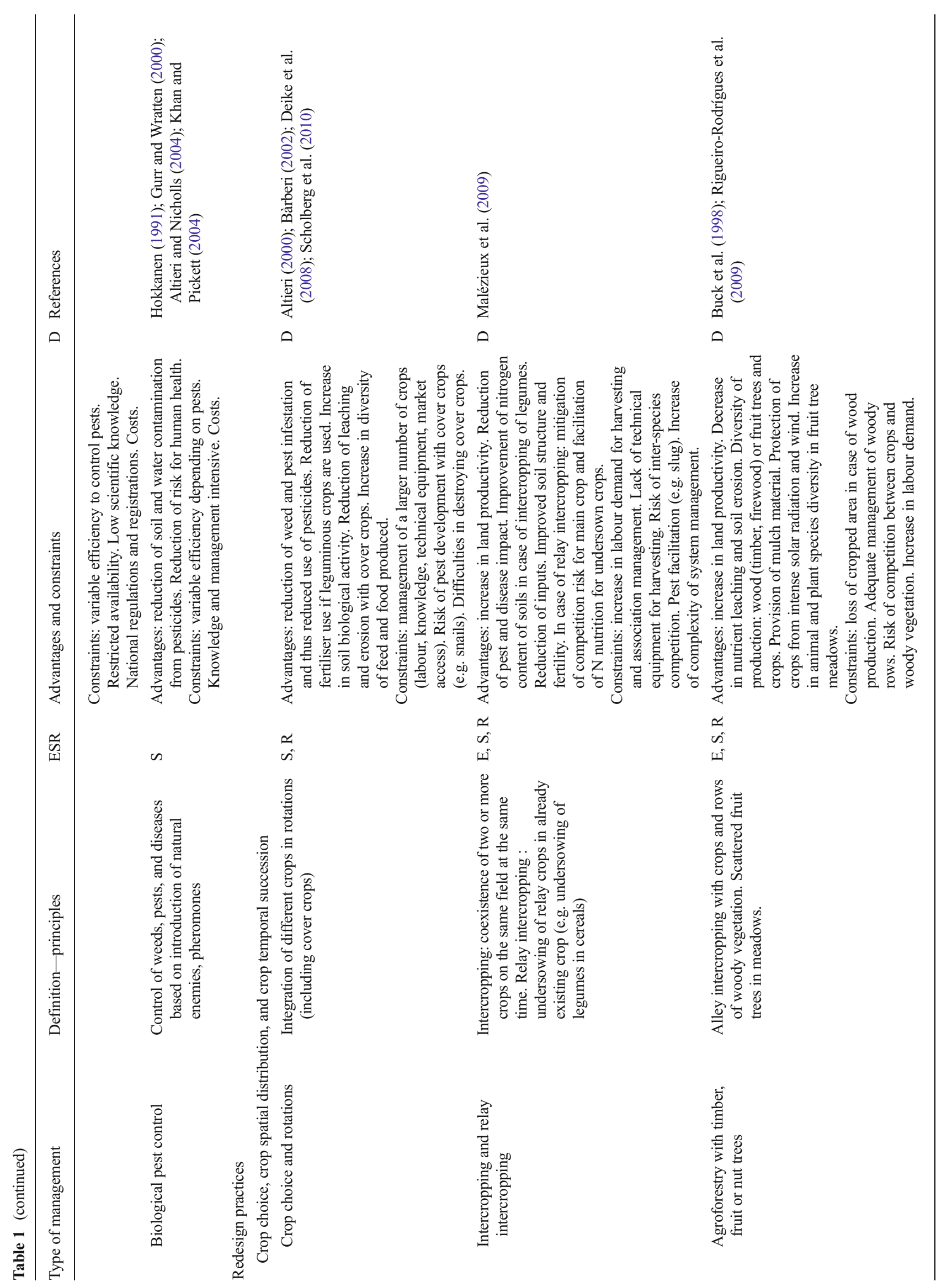




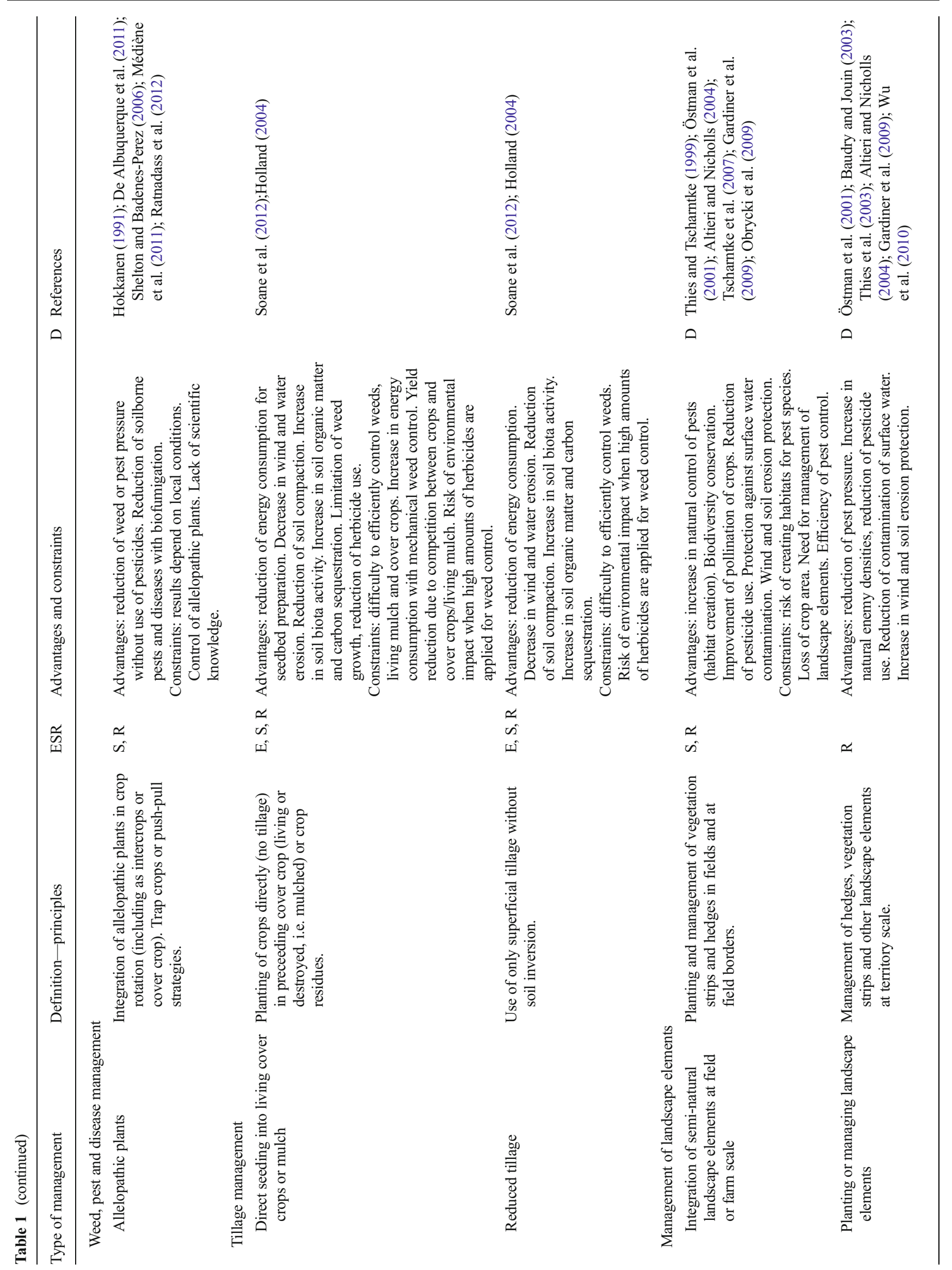


3.1 Crop choice, crop spatial distribution, and crop temporal successions

Choosing an adequate crop and cultivar can help to improve crop resistance to abiotic stresses ( $\mathrm{N}$ and water deficiency), pathogens, and diseases (Tilman et al. 2002). Plant breeding (hybrid and conventional breeding) is thus an option for developing agroecological practices, considering both cost and availability to farmers as important constraints (Table 1). Moreover, crop resistance to a pathogen is likely to be transitory resistance, as new pathogens are concomitantly developing since crop resistance acts as a selective agent on pathogen populations (Tilman et al. 2002). Nevertheless, combining crop resistance to spatial or temporal crop diversity (rotation and spatial allocation) is a good opportunity for reducing this risk.

Another important point is to choose crop species or cultivars which favour the development of beneficial soil microorganisms. These beneficial microorganisms are mainly located in the soil rhizosphere and stimulate plant growth by different mechanisms (enhanced nutrient acquisition, protection against pathogens, and modulation of phytohormone synthesis). Arbuscular mycorrhizal fungi (AMF) constitute a key functional group that favours crop growth and agroecosystem sustainability. Soil characteristics, soil management and plants influence their development and effectiveness for plant productivity (Gianinazzi et al. 2010). Crop choice and crop rotation are important factors to consider in order to favour their development. The diversification of crop rotations and the reduction of non-mycorrhizal crops (e.g. rapeseed) could enhance arbuscular mycorrhizal fungi populations and diversity. Gianinazzi et al. (2010) also highlight the importance of changing breeding strategies from a selection of plants adapted to high fertilisers and biocide usage, to a selection of plants adapted to AMF attributes. Plant growthpromoting rhizobacteria (PGPR) constitute another key functional group that favours crop development by increasing the supply or availability of nutrients to the host plant or by helping to control pathogenic organisms (Malusá et al. 2012; Vessey 2003). Numerous cropping practices influence the density and effectiveness of PGPR, for example, tillage, organic amendments, or liming. Crop species and cultivar also influence these microbial communities (Hartmann et al. 2009). Breeding strategies and biotechnology, through the manipulation of root exudates, have the potential to improve plant nutrition and protect plants from stresses, but improvement of nutrient availability has yet to be determined (Ryan et al. 2009).

In general, crop or cultivar choices help to improve the efficiency of cropping systems, reduce pesticide use, and can be implemented in a substitution stage. Resource use efficiency can be improved by planting or sowing a crop with lower needs after a nutrient or water demanding crop. Improving 
Fig. 3 Different categories of agroecological practices identified in the review. Their scale of application ranges from field scale to landscape scale. Most practices are either applied at the field or cropping system scale. The arrow with weed, pest, and disease management practices indicates that they are also applied on the field scale and landscape level

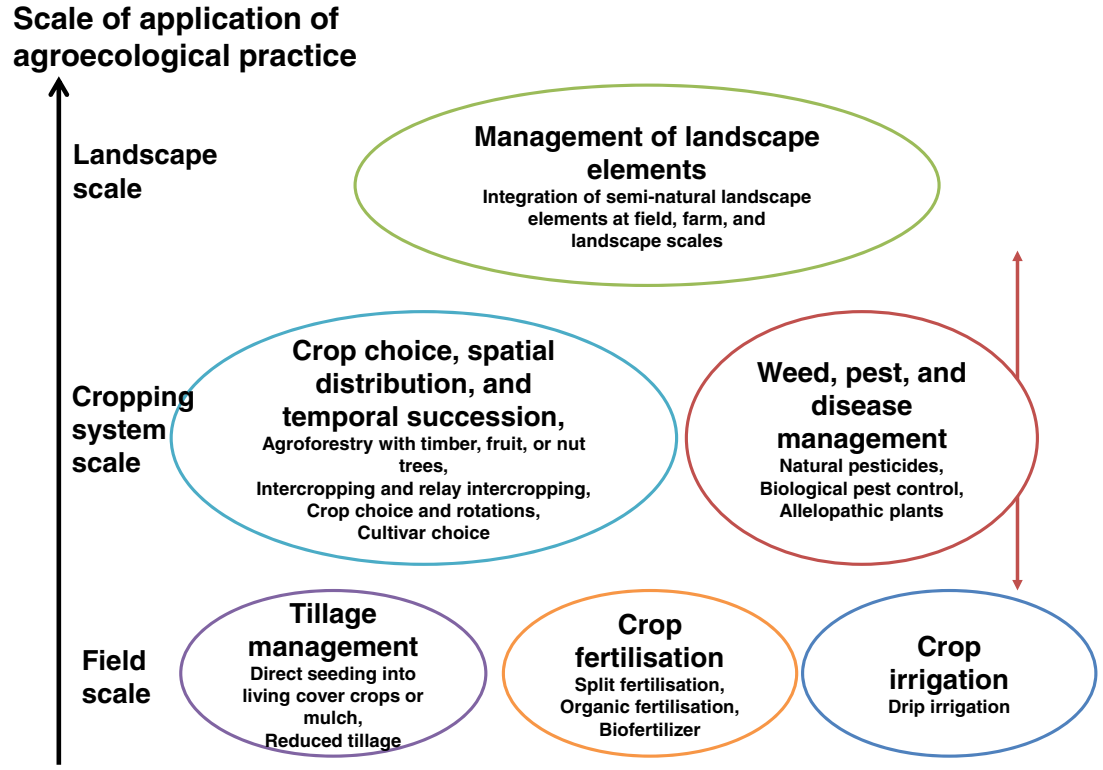

water use efficiency in water-scarce conditions (particularly rainfed water) is possible with relevant crop rotations (Pala et al. 2007; Salado-Navarro and Sinclair 2009; Turner 2004). Moreover, in conditions where rainfall events are sporadic and sometimes violent (storms in the Mediterranean climate, for example), cover crops can play an important role by reducing surface runoff and permitting a better water infiltration, possibly gainful for the next crop (Celette et al. 2008; Gaudin et al. 2010).

\subsection{Crop fertilisation management}

Splitting $\mathrm{N}$ fertiliser application is an effective means of improving $\mathrm{N}$ use efficiency in agricultural crop production (Table 1). The objective is to match the supply of $\mathrm{N}$ to the crop $\mathrm{N}$ demand in time (Fageria and Baligar 2005; Zebarth et al. 2009). The timing of applications could be triggered depending on the actual $\mathrm{N}$ uptake of the crop, which can be measured or estimated with the use of different tools (Lemaire et al. 2008). This improved matching of supply and demand would help to improve the efficiency of the practice and to limit ground and surface water contamination by fertilisers. However, it requires increased labour; the estimation of crop $\mathrm{N}$ demand might be difficult.

Utilisation of biofertilisers is another way to reduce fertiliser inputs and improve nutrient availability. They are "substances which contain living microorganisms which, when applied to seed, plant surfaces, or soil, colonise the rhizosphere or the interior of the plant, and promote growth by increasing the supply or availability of primary nutrients to the host plant" (Vessey 2003). Three major groups of microorganisms are considered biofertilisers: AMF, PGPR, and nitrogen fixing rhizobia (Malusá et al. 2012). The latter is used with legumes and has existed for over a century.
Commercialization of PGPR and AMF inoculants remains low besides the utilisation of an Azospirillum inoculant, which is available for a variety of crops in Europe and Africa (Vessey 2003). Some experiments have reported plant growth promotion, increased yield, and uptake of $\mathrm{N}$ and some other elements through PGPR inoculation (Singh et al. 2011) or AMF inoculation (Ortas 2012; Pellegrino et al. 2011). Biofertilisers can decrease the use of synthetic fertilisers and reduce environmental pollution to a considerable extent. But this technology needs further improvement and a better understanding of the different conditions and features of the interrelationships in the soil-plantmicroorganism system in the field (Malusá et al. 2012). Indeed, the effect of biofertilisers on plant growth has been frequently hampered due to the variability and inconsistency of results between laboratory, greenhouse, and field studies.

Organic fertilisation is a way of substituting inorganic fertilisers and of improving the efficiency of fertilisation by improving general soil fertility. However, it can also lead to a necessary redesign of the system. Application of organic fertiliser causes enhanced soil biological activity (Birkhofer et al. 2008; Steenwerth and Belina 2008) and potentially increased soil mineralisation. Nevertheless, the constraints of these practices may include higher labour and energy demands, and difficulty in optimising $\mathrm{N}$ availability in soils with organic fertilisation as well as in matching plant demand (Sanchez et al. 2004). Moreover, obtaining offfarm organic fertilisers might be difficult, expensive, and may even incur undesirable transport costs, e.g. manure. Finally, the introduction of more organic fertilisers into the cropping system may entail introducing livestock into the farm. This would imply a redesign of the whole farming system. 


\subsection{Crop irrigation}

Drip irrigation, especially in horticultural systems, offers a high potential to limit water inputs, to improve water use efficiency, and to better match the crop water demand in time and space (Table 1). It also limits the risk of soil salinization. The major constraints are the high investment and management costs. A combination of drip irrigation and cover crops is also possible by adding cover crop rows between crops to reduce evaporation from bare soil, decrease soil erosion, increase soil organic matter, and increase $\mathrm{N}$ concentration if legumes are used (Lopes et al. 2011). Cover crops could also play the role of mulch.

\subsection{Weed, pest, and disease management}

The use of natural pesticides is an agroecological practice that replaces synthetic pesticide use (Table 1). Natural pesticides, often also called botanical pesticides or botanicals, have a high potential as an alternative to synthetic pesticides and their associated negative effects. Nevertheless, still not much is known about them, particularly regarding larger-scale applications in agriculture. Some of them may also cause environmental pollution. Only a few natural pesticides are presently commercially used due to constraints of variable efficiency of pest control, availability, national regulations and registration, and costs (Isman 2008). Among botanical pesticides are, for example, pesticides which are (1) derived from the seeds of the trees, (2) based on plant essential oils, (3) based on pyrethrum extracted from flowers, (4) derived from crude aqueous extracts of plants, and (5) based on extracts of trees (Batish et al. 2008; Charleston et al. 2005; Coulibaly et al. 2002; Isman 2006, 2008; Mordue and Nisbet 2000; Regnault-Roger and Philogène 2008; Sinzogan et al. 2006). Although these botanical pesticides are rather marginal compared to other biocontrol methods, they will be of particular interest for the growing organic sector where synthetic pesticides are not allowed, as well as for traditional agriculture in developing countries, as many of them are derived from tropical or subtropical plants that grow naturally in such countries (Isman 2006, 2008; Regnault-Roger and Philogène 2008).

In addition to botanical pesticides, the so-called biopesticides are also used. This includes the application of bacteria, AMF inoculants, or other fungi that can control deleterious organisms (Vessey 2003; Whipps 2001). Biopesticides impact pests by antibiosis, competition, induction of plant resistance mechanisms, inactivation of pathogen germination, and/or degradation of the pathogenicity of the pathogens (Whipps 2001). Nevertheless, field application often fails to counteract pathogen development due to insufficient rhizo- and/or endosphere colonisation (Compant et al. 2010; Verbruggen et al. 2013).
Biological pest control includes different agroecological practices that reduce or replace pesticide use (Table 1). Biological pest control is based on the substitution of chemical pesticides by releasing natural enemies into the agroecosystems. Using pheromones to disturb sexual reproduction of targeted insect pests is another biological control option.

Natural pesticides and biological pest control reduce the risk of water pollution and risks to human health (e.g. Altieri and Nicholls 2004; Gurr and Wratten 2000). They might be difficult to apply as their efficiency and availability depends on the pest, because they involve increased management and costs and require knowledge.

To summarise, we defined seven categories of agroecological practices that rely either on increasing efficiency by reducing input consumption and increase crop productivity, or on substitution practices that substitute an input or a practice. These agroecological practices are: crop choice, splitting fertilisation, biofertilisers, organic fertilisation, drip irrigation, biological pest control, and natural pesticides.

\section{Redesign agroecological practices}

Redesign practices signifies that the whole, or at least a large part, of the cropping system should be rethought with the adoption of the practice in question. This redesign is often carried out together with a diversification of systems in increasing the diversity of cultivars, crops in the rotation, or in valorising natural biodiversity for conservation biological control.

4.1 Crop choice, crop spatial distribution, and crop temporal succession

\subsubsection{Cover crop/green manure}

Use of cover crops is a widely applied agroecological practice to limit fertiliser inputs and reduce risk of water contamination due to a decreased risk of leaching (Sanchez et al. 2004; Scholberg et al. 2010), and also to reduce soil or wind erosion. Integration of cover crops into the rotation automatically incurs crop diversification (Table 1). Soil biological activity is also enhanced, and in the case of use of legumes, there is provision of $\mathrm{N}$ supply for the next crop (Birkhofer et al. 2008; Steenwerth and Belina 2008). Leguminous plants can be an important source of easily absorbable nitrogen for other crops in the rotation due to their ability to fix atmospheric nitrogen (Fustec et al. 2010). They also release large amounts of labile carbon compounds promoting microbial growth and improving soil structure (Shepherd et al. 2002). However, cover crop practice constraints include a higher labour demand and potential risk of pest development, e.g. snails under cover crops. Certain species can also be incorporated into the crop rotation 
in order to decrease pest pressure. For example, Brassica crops can function as cover and trap crops, but also as biocontrol, biofumigant, and biocidal agents against certain insects and pathogens (Ahuja et al. 2010).

\subsubsection{Crop temporal successions}

Crop rotation is a more classic way to introduce crop diversity into an agroecosystem. It consists in managing the crop succession to optimise positive interactions and synergies between crops. As crop presence during the rotation is normally sequential, interactions between species are mostly indirect, and also depend on crop management and growth conditions. In general, crop rotation affects soil fertility, therefore influencing plant production as well as the prevalence of pests and diseases (Altieri 1995).

First, cropping sequences can be optimised to improve nutrient availability and to limit fertiliser need. For example, integration of leguminous plants into the rotation allows fixing atmospheric nitrogen, and provides an important source of easily absorbable nitrogen for subsequent crops. Second, certain crop rotations favour soil protection and conservation by increasing soil cover, e.g. with the introduction of cover crops or favouring winter crops, but also by improving carbon content and soil fertility which permits an increase in soil stability (Dogliotti et al. 2004; Watson et al. 2002). Root systems of the subsequent crop play an important role as their roots (as crop residues) stimulate soil biological activity and improve soil structural stability. Up to $40 \%$ of the microbial carbon uptake comes from root systems, e.g. exudates or root turnover (Richardson et al. 2009). In this sense, introduction of cover crops and catch crops into the rotation is a potentially good option (Bilbro 1991; Bruce et al. 1991; Nearing et al. 2005; Wu et al. 2010). Additionally, as mentioned before, they can mitigate nitrate leaching and improve nutrient use efficiency. Under temperate conditions, they are also likely to improve water infiltration during the winter period and to increase water availability for the following crops (Celette et al. 2008; Justes et al. 2002).

Third, crop rotations can also be an efficient way to reduce pest and disease prevalence by diversifying crops in the cropping sequence while avoiding the presence of successive host crops for diseases (Colbach et al. 1997a, b). In addition, crop management, e.g. crop residues and fertilisation, play an important role. Fourth, crop rotation is known to be an efficient way to reduce weed infestation. This is due to the specific ability of some crops to rapidly cover the soil, thus competing with weeds for soil and light resources. In addition, crop management is important for weed control with different possible weeding interventions at different moments during the year (Anderson 2007; Bàrberi 2002; Koocheki et al. 2009).

Optimising ecological services cannot be the only approach to better manage crop rotations. An important point for redesigning the crop rotation system is to maintain good farm productivity and profitability. This consists, then, in optimally allocating resources, e.g. land, time, energy, fertilisers, and water, to improve profitability, productivity, and ecological services (Dogliotti et al. 2003; Dury et al. 2011).

\subsubsection{Crop spatial distribution —intercropping and agroforestry}

Intercropping may be defined as the coexistence of two or more crops in the same field at the same time (Table 1). Different spatial arrangements of these species are possible; the intensity and type of interactions will depend on the chosen arrangement and associated species (Malézieux et al. 2009). Interactions can be positive (facilitation) or negative (competition). The simplest differentiated crop mixtures (or mixed intercropping) are row and strip intercropping where at least one of the associated crops is planted in a row (or strip). These arrangements consist of "full intercropping", where interactions between associated species occur throughout the crop cycle. This differs with relay intercropping, where two or more crops are grown together only for part of their life cycles, thus limiting interactions between species (Vandermeer 1989). Other categories sometimes mentioned are associations partially composed of perennial species (e.g. agroforestry—see below).

The intercropping systems are assumed to have potential advantages in productivity, stability of outputs, resilience to disturbance, and ecological sustainability, though they are generally considered harder to manage (Vandermeer 1989; Fig. 4). The main issue in such a system is managing competition for resources between the associated crops (Ong 1995; Ozier-Lafontaine et al. 1998; Van Noordwijk et al. 1996;

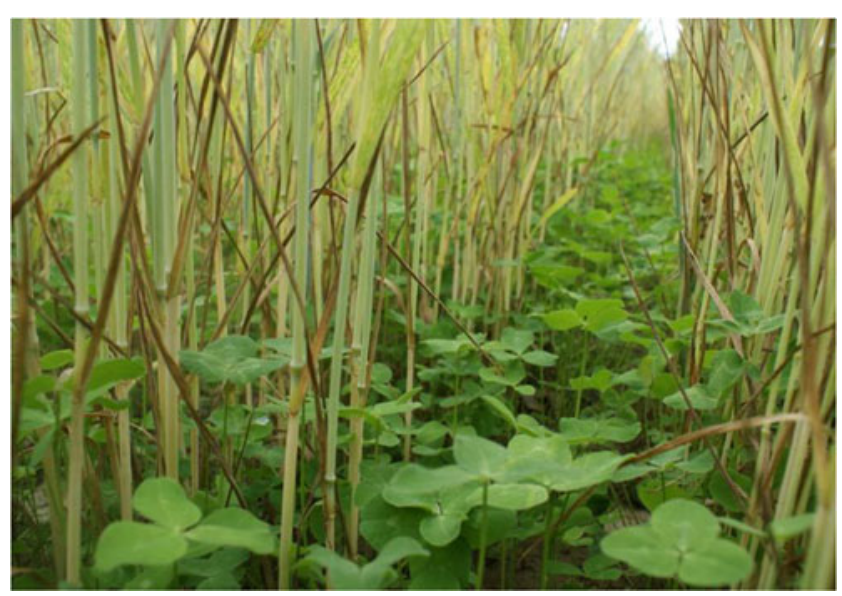

Fig. 4 Relay intercropping of wheat and undersown clover in southeastern France. In relay intercropping, leguminous species are often sown some weeks after the crop to reduce the risk of competition between crops. They assure a supplementary soil cover in particular after crop harvest. There, they limit nutrient leaching, wind, and water erosion, fix Nitrogen, and can potentially be harvested as forage (photo by F. Boissinot) 
Willey 1990). The first interest of intercropping is to improve land productivity by favouring complementarity of associated crops. Intercropping generally permits improvement of resource use efficiency, notably radiation use (Bedoussac and Justes 2010; Ozier-Lafontaine et al. 1997; Sinoquet and Caldwell 1995). In some situations, increased resource use efficiency is the consequence of a facilitation process (e.g. association with legume species; Jensen et al. 2010; Köpke and Nemecek 2009; Schmidtke et al. 2004). Root exudates of some legume species can improve soil phosphorus availability (Ae et al. 1990), solubilizing soil organic phosphorus, but also improve organic fertilisation (Li et al. 2005; Midmore 1993). Other types of facilitation may be observed when one of the associated crops offers a service to the other. For example, when wheat was associated with a clover grass, twice as much earthworms were observed in the soil than with a sole crop (Schmidt et al. 2003). As another example, cereal crops can help pea crops mitigate weed infestation due to their better competitivity and higher resource use efficiency in an intercropped system than as a sole pea crop (HauggaardNielsen et al. 2001, 2006). Intercropping also improves soil physical structure and soil fertility. Compaction and penetration resistance are lower in such systems, and there is an improvement in structural stability (Carof et al. 2007; Latif et al. 1992). Moreover, soil cover is generally increased with intercropping, mitigating both soil crusting and erosion (Le Bissonnais et al. 2004).

Different types of agroforestry practices can be also considered agroecological practices since they reduce nutrient leaching, conserve soils, increase diversity of the production system, and produce complementary wood for various uses (e.g. Buck et al. 1998; Rigueiro-Rodrígues et al. 2009). In Europe, there are different agroforestry systems that integrate crops and, more generally, woody plants (Rigueiro-Rodrígues et al. 2009; Fig. 5). However, there are also more specialised systems that include fruit or nut tree integration. In some cases, these fruit or nut tree systems are coupled with extensive grazing of meadows below or between the trees. In general, constraints for intercropping and agroforestry systems are higher management needs, loss of cropped land for the main crop, and often a higher labour demand.

\subsection{Weed, pest, and disease management—allelopathic plants}

Some plant species have the ability to produce chemical compounds which negatively influence the growth and development of weeds, pests, or diseases (De Albuquerque et al. 2011; Kruidhof et al. 2008; Tabaglio et al. 2008; Weston 1996). Therefore, the introduction of so-called allelopathic plants into crop rotations is a promising agroecological practice intending to reduce pesticide use while providing good crop yields. Allelopathic plants may be used as intercrops or cover crops. They have a direct effect on target organisms by

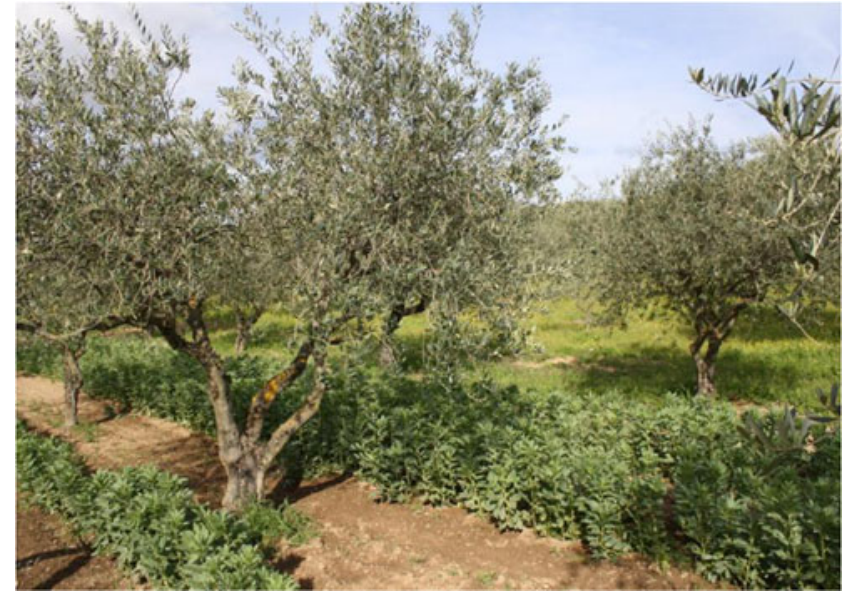

Fig. 5 Olive tree agroforestry system with undergrowth of leguminous species and grassland in Sardinia, Italy. This type of agroforestry system allows combining different crops on the same field. Resource use efficiency is increased because of different root systems, better nutrient cycling can be expected, legumes fix nitrogen, and below tree species cover the soil and wind and water erosion (photo by M. Casagrande)

releasing noxious compounds during their life cycle, or an indirect effect through the decomposition of their residues. Some crops such as rye, sorghum, or sunflower can be used as green manure or cover crops due to their direct allelopathic effects: inhibition of weed seed germination and/or development due to the release of root exudates (De Albuquerque et al. 2011). An onion crop may be regarded as a "push" crop because, when cropped together with carrot, it directly reduces attacks of carrot fly by releasing deterrent compounds (Uvah and Coaker 1984 cited in Ratnadass et al. 2012). In comparison, Brassicaceous crops primarily act indirectly on weeds, pests, and diseases through the decomposition of their residues in the soil (Médiène et al. 2011; Ratnadass et al. 2012). This delayed allelopathic effect, called biofumigation, has the ability to reduce soil-borne pests and diseases such as fungi (Médiène et al. 2011), bacteria, and nematodes (Ratnadass et al. 2012).

Allelopathic effects are not only negative for organisms. Their positive effects can be used for managing pests and diseases. In that case, the allelopathic compounds attract the target organism(s) and the plant actually acts as a "trap" crop (Hokkanen 1991; Shelton and Badenes-Perez 2006). For example, crops can be used as cover crops or intercrops because they stimulate weed germination, thus reducing the soil seed bank (Scholte 2000a, b; Scholte and Vos 2000 cited in Ratnadass et al. 2012). The push-pull strategy is based on repelling or deterring insect pests from crops (push), and then attracting them with trap plants around or even within fields to "pull" them away from crops (e.g. Khan and Pickett 2004).

Although there is a wide range of possibilities to benefit from allelopathic plants in temperate agroecosystems, so far, this type of practice is not widely applied. First, there is a lack of understanding of the biological processes. Second, 
efficiency and results are highly variable depending on local conditions (De Albuquerque et al. 2011; Médiène et al. 2011), and third and allelopathic crops can also behave as pathogenhost (Ratnadass et al. 2012).

\subsection{Tillage management}

Shifting from conventional to reduced tillage or no tillage (direct seeding) helps to reduce energy consumption, decreases wind and water erosion, reduces soil compaction, increases soil biota activity, increases soil organic matter, and thus carbon sequestration (Table 1).

No tillage corresponds to tillage practices without soil disturbance, such as direct seeding into a living crop or mulch (Fig. 6). Specific machinery may be used, such as direct seeders, which are comprised of coulter discs or tines for cutting and opening furrows for seeding. Reduced tillage corresponds to minimal soil disturbance without soil inversion (in contrast to ploughing). The soil is only worked to a depth of 5-15 cm before seeding. The main goal is to reduce soil disturbance and preserve organic matter (fresh crop residues) at the soil surface or in the first few centimetres of the soil. Many authors have discussed advantages of these practices for improving soil fertility (El Titi 2003; Holland 2004), with a high impact on soil fertility with no tillage and with a lower impact on soil fertility with reduced tillage. Reduced or no tillage practices are currently spreading throughout the world, including temperate areas (Holland 2004; Peigné et al. 2007; Soane et al. 2012).

Reduced or no tillage practices help reduce energy inputs and thus increase cropping system efficiency. Other advantages are protecting the soil from erosion (organic matter at the soil surface), stocking organic $\mathrm{C}$ (less $\mathrm{C}$ mineralisation), and

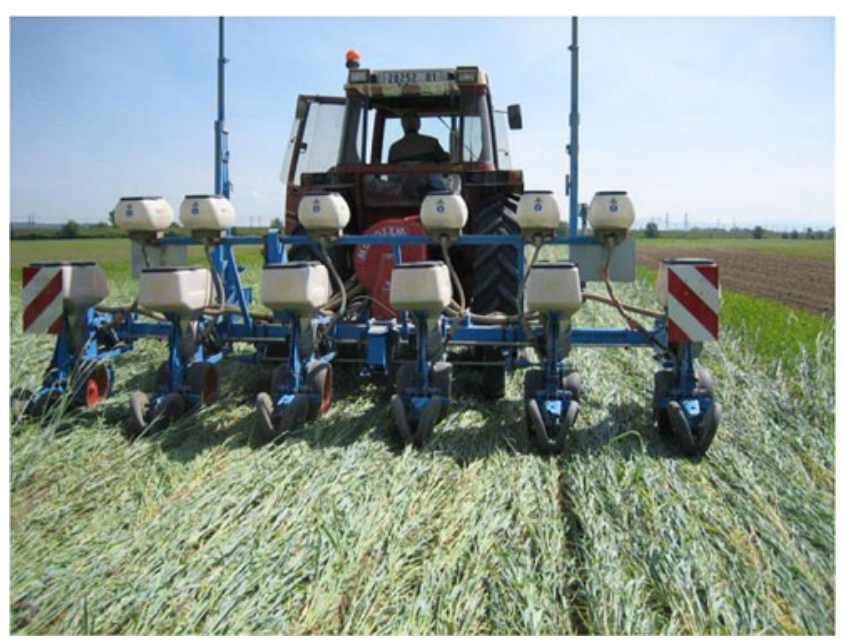

Fig. 6 Direct sowing of soybean into rye in southeastern France. This practice allows permanent soil cover and thus control weeds, decrease nutrient leaching, wind, and water erosion. Also soil organic matter is increase and higher soil biota activity achieved which leads to improve soil fertility (photo by J. Peigné) favouring soil biodiversity to promote biological activity (Ball et al. 1998; Vian et al. 2009). For instance, with no tillage more anecic earthworms were found (Capowiez et al. 2009; Peigné et al. 2009; Pelosi et al. 2009) which increased soil porosity and thus improved water and root penetration into the soil. The impact of reduced tillage may also be found on earthworm abundance, but to a lesser extent than under no tillage management (Peigné et al. 2009). Moreover, a better control of certain pests can be expected because increased numbers of predators, such as ground beetles, are found in no tillage conditions (Kromp 1999).

Although no tillage and reduced tillage are promising practices, there are still considerable constraints for adoption. A primary one is weed control. In conventional agriculture, reduced tillage can also mean increased use of chemical fertilisers and pesticides to control weeds and maintain yields (Teasdale et al. 2007). For no tillage systems with direct seeding into mulch, the increase of herbicides is due to destroying the cover crop. In organic farming, reduced tillage often results in increasing the machine traffic for weed control, and thus increasing labour time and energy costs (Peigné et al. 2007). In temperate climates, soil compaction can occur due to climatic and soil conditions, such as in the northern part of Europe (Soane et al. 2012). All these constraints result in no clear conclusion regarding their effect on crop yields. According to Soane et al. (2012), in Europe, it seems that the yields of winter crops with no tillage or reduced tillage are comparable to conventional tillage with ploughing, whereas the yields can decrease for spring crops.

To alleviate constraints and increase efficiency, introduction of such practices implies redesigning the cropping systems. For instance, to better control weeds, it is necessary to rethink the cropping system as a whole, e.g. modifying the choice of crops and crop rotations.

\subsection{Management of landscape elements}

More recent agroecological practices and approaches are the integration, or re-integration, of natural or semi-natural landscape elements such as hedges and vegetation strips, either in or around the field (Fig. 2), or at a landscape scale. Landscape elements have good potential to provide habitats and overwintering sites as well as resources such as alternative prey for beneficial insects or other pest predators (Fig. 1), thus reducing the need for pesticide applications. Due to higher natural plant diversity and flowering, they can also positively influence crop pollination as they attract pollinators and host them outside the crop flowering period (Ricketts et al. 2008). The in-field and around-field landscape elements also protect against wind and soil erosion and against surface water contamination (Baudry and Jouin 2003; Wu et al. 2010). In addition, they generally assure biodiversity conservation in agricultural areas. The major constraints of these landscape 
elements are that they may also harbour habitats for pest species, and that the efficiency for natural pest control may vary considerably. In addition, they reduce the cropped area and potential food production, and have to be managed by farmers.

Current research regarding the integration of landscape elements into agricultural landscapes faces the challenge of improving biological control of pests in order to reduce pesticide use. In most cases, the diversity of habitats within landscapes greatly affects communities of herbivores and their natural enemies within an agricultural crop (Altieri and Nicholls 2004; Gardiner et al. 2009). The majority of studies show that herbivore density and crop damage decreases with increasing proportions of non-crop habitats in the landscape. For example, Thies et al. (2003) found decreased plant damage and increased larval parasitism in structurally complex landscapes. Östman et al. (2001) showed that regardless of conventional or organic farming practices, early season establishment of aphids was lower in landscapes with abundant field margins and perennial crops. Altieri and Nicholls (2004) and Obrycki et al. (2009) found that the introduction of flowering plants as strips within cropped fields enhances the availability of pollen and nectar, necessary for optimal reproduction, fecundity, and longevity of many natural enemies of pests, leading to greater abundance of aphidophagous predators and reduced aphid populations.

Although many positive effects of landscape elements and natural habitats on pest control have been observed, either in and around fields or at the landscape scale, the current challenges are to preserve the existing landscape elements and to re-establish or increase introduction to present agroecosystems and agricultural landscapes. Here, habitat thresholds play an important role. With and King (1999 cited in Gardiner et al. 2009) as well as Thies and Tscharntke (1999) showed that search success of natural enemies and parasitism rates declined when the non-crop area fell below $20 \%$. In addition, the impact of landscape structure is dependent not only on the total amount of suitable habitats within landscapes, but also on the spatial arrangement of habitats as herbivorous pests and their natural enemies vary in their capacity for dispersal (Gardiner et al. 2009). In their review paper, Tscharntke et al. (2007) clearly state that the enhancement of biological control needs a landscape perspective and consideration of possible interacting effects between the landscape context and local habitat quality. Even so, specific recommendations to design appropriate agricultural landscapes that effectively assure biological control are needed.

Integration and management of semi-natural elements at the landscape scale demands multi-stakeholder agreement as this has to be implemented within territorial development. In this respect, this not is a single-operator practice compared to the other agroecological practices presented in this paper.
To summarise, eight categories of agroecological practices can be distinguished that need a redesign of the whole or part of the existing cropping system before they can be adopted. Often, this includes a diversification of the system. Among these agroecological practices are crop choice and rotations; intercropping and relay intercropping; agroforestry with timber, fruit, or nut trees; allelopathic plants; direct seeding into living cover crops or mulch; reduced tillage; integration of semi-natural landscape elements at field or farm scale; and management of landscape elements at landscape scale.

\section{Promising agroecological practices}

\subsection{Scales of application, system change}

A broad variety of agroecological practices that improve agricultural production without an expense to the environment or biodiversity have existed for decades. Nevertheless, they are applied to various extents in different parts of the world and to different degrees within the prevailing regional or national farming systems. Whereas agroecological practices are applied by a higher share of farmers practicing integrated agriculture or organic agriculture, wide contrasts are found in conventional agriculture. In most of the highly industrialised large-scale cropping and livestock systems, the use of agroecological practices is still limited. In contrast, in less intensive conventional systems, e.g. in less-favoured hilly or mountainous areas, different agroecological practices have been more widely applied for decades as these areas have lower potential for intensive production.

The application of the different agroecological practices presented in this paper implies modifying the farming system, either at crop management scale or at the cropping or farming system scale. In the case of a single practice, the level of change is usually low because only part of the crop management has to be changed or adapted by the farmer (Table 2). This is usually the case when considering efficiency or substitution practices. For example, applying split fertilisation or changing crop cultivars that can be relatively easily implemented. In contrast, when the practices require modification of the cropping or farming system, the necessary level of system change is normally medium or high because not only a single practice, but a much larger part of the system has to be reorganised or redesigned. For example, direct seeding into living mulch might require a strong system change; new machinery is necessary to prepare fields and carry out seeding, new types of mechanical weed management have to be applied to avoid applying high amounts of herbicides, and crop rotations have to be redesigned to take into account mulch benefits. This high level of system changes explains why this agroecological practice is not yet widely applied in current agriculture. 
Table 2 Agroecological cropping practices, scale of application, level of system change, and integration in today's agriculture in Europe

\begin{tabular}{|c|c|c|c|c|}
\hline Agroecological practice & $\begin{array}{l}\text { Scale of } \\
\text { application }^{\text {a }}\end{array}$ & $\begin{array}{l}\text { Level of system } \\
\text { change needed }\end{array}$ & $\begin{array}{l}\text { Level of integration } \\
\text { in today's agriculture }\end{array}$ & $\begin{array}{l}\text { Potential for the } \\
\text { next decade }\end{array}$ \\
\hline \multicolumn{5}{|l|}{ Efficiency increase and substitution practices } \\
\hline \multicolumn{5}{|l|}{ Crop choice, crop spatial distribution, and crop temporal succession } \\
\hline Cultivar choice & Practice & Low & High & High \\
\hline \multicolumn{5}{|l|}{ Crop fertilisation } \\
\hline Split fertilisation & Practice, system & Low & High & High \\
\hline Biofertiliser & Practice & Low & Low & Medium \\
\hline Organic fertilisation & Practice, system & Medium & Medium & Medium \\
\hline \multicolumn{5}{|l|}{ Crop irrigation } \\
\hline Drip irrigation & Practice & High & Medium & High \\
\hline \multicolumn{5}{|l|}{ Weed, pest, and disease management } \\
\hline Natural pesticides & Practice & Low & Low & Medium \\
\hline Biological pest control & System & Medium & Medium & High \\
\hline \multicolumn{5}{|l|}{ Redesign practices } \\
\hline \multicolumn{5}{|l|}{ Crop choice, crop spatial distribution and crop temporal succession } \\
\hline Crop choice and rotations & System & Medium & Low & High \\
\hline Intercropping and relay intercropping & Practice, system & High & Low & Medium \\
\hline Agroforestry with timber, fruit or nut trees & System & High & Low & Low \\
\hline \multicolumn{5}{|l|}{ Weed, pest and disease management } \\
\hline Allelopathic plants & Practice, system & Low & Low & Medium \\
\hline \multicolumn{5}{|l|}{ Tillage management } \\
\hline Direct seeding into living cover crops or mulch & System, practice & High & Low & Low/medium \\
\hline Reduced tillage & System, practice & High & Medium & Medium/high \\
\hline \multicolumn{5}{|l|}{ Management of landscape elements } \\
\hline Integration of semi-natural landscape elements at field or farm scale & System, practice & Medium & Low & Medium \\
\hline Management of landscape elements at landscape scale & Landscape & High & Low & Low \\
\hline
\end{tabular}

${ }^{\text {a }}$ Practice $=$ only the specific practice has to be changed or adapted. System $=$ the cropping or farming system has to be changed or adapted. Landscape $=$ multi-stakeholder agreement is necessary to apply management

Diversification plays an important role when implementing many agroecological practices. This is accomplished, for example, with the integration of more diverse cultivars, crops, or intercrops in the cropping system, use of agroforestry systems, and valorisation of semi-natural landscape elements for conservation biological control. The overall objective is to valorise different ecosystem services linked to diversification in order to increase resilience of agroecosystems to perturbation, to decrease pest outbreaks (including weeds) or control them at an acceptable level, and to conserve (agro)biodiversity. Nevertheless, to implement the agroecological practices that are based on diversification, a redesign of cropping systems is often necessary because the general trend after the green revolution was, contrarily, to simplify production systems.

5.2 Integration in today's agriculture and promising agroecological practices

In general, most of the agroecological practices presented in this paper remain today at a low level of application in agriculture (Fig. 7). The two practices that are currently widely applied are split fertilisation and use of cultivars from plant breeding. This seems to be due to their longer existence and the high level of experience and knowledge that have been developed for two or three decades, but also because they do not require a high level of system change (Table 2). Integration of organic fertilisation, cover crops, drip irrigation, and biological pest control has already reached a medium level of integration in today's agriculture. The latter three, together with split fertilisation and the use of plant breeding cultivars, have, in our opinion, a high potential to be more broadly implemented in the next decade because they already benefit from good scientific knowledge as well as broad experience of farmers.

In addition, legislative regulations and laws in Europe or at national levels, such as the Nitrate Directive, Water Framework Directive, Pesticides Framework Directive, the greening of the second pillar of the Common Agricultural Policy in Europe, and agri-environment schemes, will probably boost implementation of more environmentally friendly 
Fig. 7 Potential of agroecological practices for the next decade in relation to their integration in today's agriculture. Most practices have so far a low integration in today's agriculture, and only low or medium potential for the next decade to be more broadly implemented. In contrast, organic fertilisation, reduced tillage, drip irrigation, biological pest control, cultivar choice, and split fertilisation have already medium or high integration levels in today's agriculture, and medium or high potential for the future

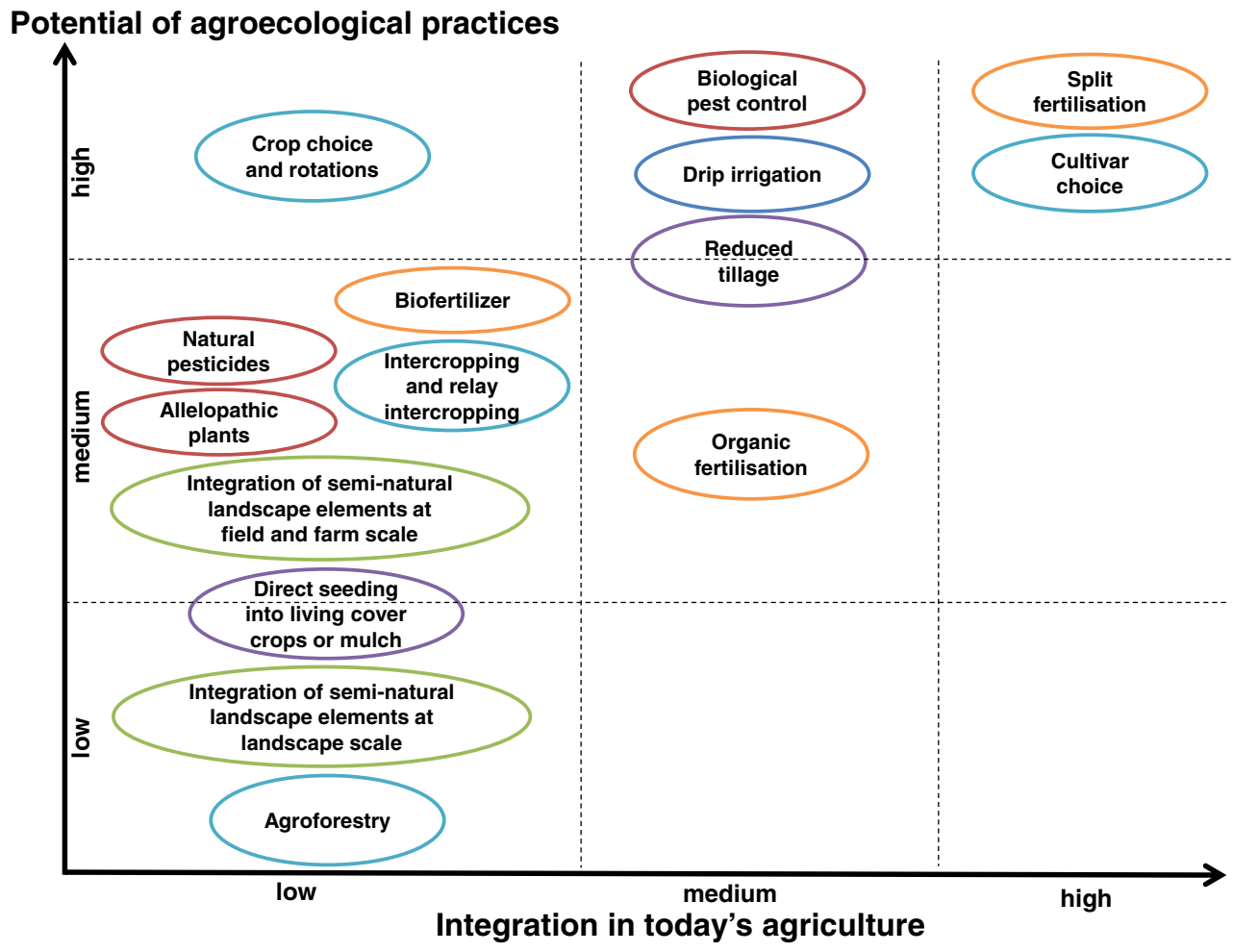

practices that are less polluting and less reliant on external inputs. These regulations could enhance an extended use of split fertilisation, cover crops, diversified crop rotation, and biological control.

Nevertheless, most of the agroecological practices only have a medium potential for a broad implementation in the next decade. This is due to still-limited scientific knowledge or low practical on-farm experience with practices such as direct seeding and relay intercropping, and the use of natural pesticides and application of biopesticides in agriculture. A major constraint for direct seeding and intercropping is still their agronomic performance as yields are very variable (Malézieux et al. 2009; Soane et al. 2012). Natural and botanical pesticides as well as biopesticide application will probably not be used on larger areas in the next decade.

In contrast, practices such as direct seeding into living mulch or cover crops and the integration of landscape elements around fields that we classified as medium or low potential for the next decade might even develop much faster than expected as much research is currently carried out on these topics, but also because an increasing number of farmers or farmer groups own the development of these practices.

Integration of allelopathic plants, biofertiliser, agroforestry systems, and management of landscape elements at field scale have a low level of integration in today's agriculture and will, in our opinion, not be broadly implemented in the near future. A landscape-based integration of landscape elements will strongly depend on the regional and national general conditions, as it involves a larger scale of management. Moreover, this type of agroecological practice/approach can probably only be implemented in the framework of territorial development projects and planning. The main constraints for the development of practices based on allelopathy are low scientific knowledge and practical experience, and difficulties to manage allelopathic plants. Although agroforestry systems exist in many European regions, the combined management of trees and meadows, for example, is considered an "old-fashioned" system without high yield potential. The surface areas of these systems are presently decreasing, although some national support programs do exist (Rigueiro-Rodrígues et al. 2009).

What can be generally expected from agroecological practices in the following years? Although some of them are already quite well known, most of them will not be applied in the near future at larger scales. It seems more realistic that we will still have to focus on core production areas with high inputs to guarantee high yields, but in setting clear rules against environmental degradation and pollution as well as biodiversity loss. A broader dissemination of agroecological practices will probably happen first in less-favoured agricultural areas or low potential production zones.

In contrast to temperate zone agriculture, potential for yield increases with agroecological practices are much higher in developing countries as they are usually not at yield maximums, except for irrigated rice systems. Pretty et al. (2003) and De Schutter $(2011,2012)$ summarised such examples from 
tropical and subtropical countries. Nevertheless, as in the case for temperate zone agriculture, many of these agroecological practices with high potential in developing countries are not yet widely applied (Altieri 2000; Wezel and Rath 2002).

To summarise, most agroecological practices have so far a low integration in today's agriculture, and only low or medium potential for the next decade to be more broadly implemented. In contrast, organic fertilisation, reduced tillage, drip irrigation, biological pest control, cultivar choice, and split fertilisation have already medium or high integration levels in today's agriculture, and medium or high potential for the future.

\section{Outlook beyond agroecological practices}

Even in widely applying and further developing agroecological practices, and with this improving agricultural production in terms of quantity and quality, more requirements are necessary to feed the planet by 2050 . According to the scenarios developed in the Agrimonde report (INRA and CIRAD 2009), which are based on scenarios of the Millennium Ecosystem Assessment report (2005), it also requires (1) major shifts in food consumption trends, in particular breaking the relationship between higher revenue and higher consumption of animal products; (2) large investments in infrastructure, research, and development not to only increase yields, but to develop agricultural systems that are compatible with ecosystem preservation and resistance to climate change; (3) proactive policies at different levels to improve structural development in agricultural systems and consumption, as well as to regulate food trade; and (4) reducing losses at all levels (storage, transport, processing, distribution, and consumption).

Nevertheless, production practices remain the central and crucial point as they are the primary factor to produce food for future generations. Here, agroecological cropping practices can and should play a central role.

\section{Conclusions}

Most agroecological practices such as biofertilisers; natural pesticides; crop choice and rotations; intercropping and relay intercropping; agroforestry with timber, fruit, or nut trees; allelopathic plants; direct seeding into living cover crops or mulch; and integration of semi-natural landscape elements at field or farm scale; or their management at landscape scale have so far a low integration in today's agriculture. They have only low or medium potential to be more broadly implemented in the next decade. In contrast, organic fertilisation, split fertilisation, reduced tillage, drip irrigation, biological pest control, and cultivar choice have already medium or high integration levels in today's agriculture, and medium or high potential for the future.
The most important parameters for a limited or broader application today are if (1) the practices have already existed for a significant period of time, (2) there exists widespread farming and good scientific knowledge about the practices, (3) there exists practical on-farm experience, and (4) a system change and redesign of cropping systems is required.

To feed a growing world population, we need practices that provide sufficient food that are not at the detriment or risk to the environment and that assure economic viability for farmers. Here, agroecological cropping practices can and should play a central role.

Acknowledgments We highly appreciate the numerous discussions we had with many colleagues in France and elsewhere in the world about what constitute an agroecological practice, and which are qualifying agricultural practices.

\section{References}

Ae N, Arihara J, Okada K, Yoshihara T, Johansen C (1990) Phosphorus uptake by pigeon pea and its role in cropping systems of the Indian subcontinent. Science 248:477-480. doi:10.1126/science.248.4954. 477

Ahuja I, Rohloff J, Bones A (2010) Defence mechanisms of Brassicaceae: implications for plant-insect interactions and potential for integrated pest management. A review. Agron Sustain Dev 30: 311-348. doi:10.1051/agro/2009025

Altieri MA (1995) Agroecology: the science of sustainable agriculture. Westview Press, Boulder

Altieri MA (2000) Enhancing the productivity and multifunctionality of traditional farming in Latin America. Int J Sustain Dev World 7:50 61

Altieri MA (2002) Agroecology: the science of natural resource management for poor farmers in marginal environments. Agric Ecosyst Environ 93:1-24

Altieri MA, Nicholls CI (2004) Biodiversity and pest management in agroecosystems. Food Product Press, New York

Anderson RL (2007) Managing weeds with a dualistic approach of prevention and control. A review. Agron Sustain Dev 27:13-18. doi:10.1051/agro:2006027

Arrignon J (1987) Agro-écologie des zones arides et sub-humides. G-P Masonneuve \& Larose/ACCT, Paris

Ball BC, Tebrügge F, Sartori L, Giráldez JV, González P (1998) Influence of no-tillage on physical, chemical and biological soil properties. In: Tebrügge F, Böhrnsen A (eds) Experiences with the applicability of no-tillage crop production in the West European countries, review papers, summaries and conclusions of the concerted action. JustusLiebig University, Giessen, pp 7-27

Bàrberi P (2002) Weed management in organic agriculture: are we addressing the right issues? Weed Res 42:177-193. doi:10.1046/j. 1365-3180.2002.00277.x

Batish DR, Sing HP, Kohli RK, Kaur S (2008) Eucalyptus essential oil as a natural pesticide. For Ecol Manag 256:2166-2174. doi:10.1016/j. foreco.2008.08.008

Baudry J, Jouin A (2003) De la haie aux bocages. Organisation, dynamique et gestion. INRA, Paris

Bedoussac L, Justes E (2010) Dynamic analysis of competition and complementarity for light and $\mathrm{N}$ use to understand the yield and the protein content of a durum wheat-winter pea intercrop. Plant Soil 330:37-54. doi:10.1007/s11104-010-0303-8 
Bilbro JD (1991) Cover crops for wind erosion control in semiarid regions. In: Hargrove WL (ed) Cover crops for clean water: the proceedings of an international conference, West Tennessee Experiment Station, April 9-11, 1991. Jackson, Tennessee, pp 3638

Birkhofer K, Bezemer TM, Bloem J, Bonkowski M, Christensen S, Dubois D, Ekelund F, Fließbach A, Gunst L, Hedlund K, Mäder P, Mikola J, Robin C, Setälä H, Tatin-Froux F, Van der Putten WH, Scheu S (2008) Long-term organic farming fosters below and aboveground biota: implications for soil quality, biological control and productivity. Soil Biol Biochem 40:2297-2308. doi:10.1016/j. soilbio.2008.05.007

Borlaug NE (2000) Ending world hunger. The promise of biotechnology and the threat of antiscience zealotry. Plant Phys 124:487-490. doi: 10.1104/pp. 124.2.487

Bruce RR, Hendrix PF, Langdale GW (1991) Role of cover crops in recovery and maintenance of soil productivity. In: Hargrove WL (ed) Cover crops for clean water: the proceedings of an international conference, West Tennessee Experiment Station, April 9-11, 1991. Jackson, Tennessee, pp 109-115

Buck LE, Lassoie JP, Fernandes E (1998) Agroforestry in sustainable agricultural systems. CRC Press, Boca Raton, $411 \mathrm{p}$

Capowiez Y, Cadoux S, Bouchant P, Ruy S, Roger-Estrade J, Richard G, Boizard H (2009) The effect of tillage type and cropping system on earthworm communities, macroporosity and water infiltration. Soil Till Res 105:209-216. doi:10.1016/j.still.2009.09.002

Carof M, de Tourdonnet S, Saulas P, Le Floch D, Roger-Estrade J (2007) Undersowing wheat with different living mulches in a no-till system. I. Yield analysis. Agron Sustain Dev 27:347-356. doi:10.1051/ agro:2007016

Celette F, Gaudin R, Gary C (2008) Spatial and temporal changes in the water regime of a Mediterranean vineyard due to the adoption of cover cropping. Eur J Agron 29:153-162. doi:10.1016/j.eja.2008. 04.007

Charleston DS, Kfir R, Dicke M, Vet LEM (2005) Impact of botanical pesticides derived from Melia azedarach and Azadirachta indica on the biology of two parasitoid species of the diamond back moth. Biol Control 33:131-142. doi:10.1016/j.biocontrol.2005.02.007

Colbach N, Duby C, Cavelier A, Meynard JM (1997a) Influence of cropping systems on foot and root diseases of winter wheat: fitting of a statistical model. Eur J Agron 6:61-77. doi:10.1016/S11610301(96)02033-3

Colbach N, Lucas P, Cavelier N, Cavelier A (1997b) Influence of cropping system on sharp eyespot in winter wheat. Crop Prot 16: 415-422. doi:10.1016/S0261-2194(97)00018-5

Compant S, Clément C, Sessitsch A (2010) Plant growth-promoting bacteria in the rhizo- and endosphere of plants: their role, colonization, mechanisms involved and prospects for utilization. Soil Biol Biochem 42:669-678. doi:10.1016/j.soilbio.2009.11.024

Coulibaly O, Mbila D, Sonwa JJ, Adesina A, Bakala J (2002) Responding to economic crisis in sub-Saharan Africa: new farmerdeveloped pest management strategies in cocoa-based plantations in Southern Cameroon. Integr Pest Manag Rev 7:165-172. doi:10. 1023/B:IPMR.0000027500.24459.fe

De Albuquerque MB, Santos RC, Lima LM, Melo Filho PDA, Nogueira RJMC, Câmara CAG, Ramos A (2011) Allelopathy, an alternative tool to improve cropping systems. A review. Agron Sustain Dev 31: 379-395. doi:10.1051/agro/2010031

De Schutter O (2011) Agroecology and the right to food. Report of the Special Rapporteur on the right to food. United Nations. http://www. srfood.org/images/stories/pdf/officialreports/20110308_a-hrc-1649 agroecology en.pdf. Accessed October 2011

De Schutter O (2012) Agroecology, a tool for the realization of the right to food. In: Lichtfouse E (ed) Agroecology and strategies for climate change. Sustainable agriculture reviews vol. 8. Springer, Dordrecht, pp 1-16
Deike S, Pallutt B, Melander B, Strassemeyer J, Christen O (2008) Longterm productivity and environmental effects of arable farming as affected by crop rotation, soil tillage intensity and strategy of pesticide use: a case study of two long-term field experiments in Germany and Denmark. Eur J Agron 29:191-199. doi:10.1016/j.eja.2008.06.001

Dogliotti S, Rossing WAH, Van Ittersum MK (2003) ROTAT, a tool for systematically generating crop rotations. Eur J Agron 19:239-250. doi:10.1016/S1161-0301(02)00047-3

Dogliotti S, Rossing WAH, van Ittersum MK (2004) Systematic design and evaluation of crop rotations enhancing soil conservation, soil fertility and farm income: a case study for vegetable farms in South Uruguay. Agric Syst 80:277-302. doi:10.1016/j.agsy.2003.08.001

Dury J, Schaller N, Garcia F, Reynaud A, Bergez J-E (2011) Models to support cropping plan and crop rotation decisions. A review. Agron Sustain Dev 32:567-580. doi:10.1007/s13593-011-0037-x

El Titi A (2003) Implications of soil tillage for weed communities. In: El Titi A (ed) Soil tillage in agroecosystems. CRC Press, Boca Raton, pp 147-185

Fageria NK, Baligar VC (2005) Enhancing nitrogen use efficiency in crop plants. Adv Agron 88:97-185. doi:10.1016/S0065-2113(05)88004-6

Fustec J, Lesuffleur F, Mahieu S, Cliquet J-B (2010) Nitrogen rhizodeposition of legumes. A review. Agron Sustain Dev 30:5766. doi:10.1051/agro/2009003

Gardiner MM, Fiedler AK, Costamagna AC, Landis DA (2009) Integrating conservation biological control into IPM systems. In: Radcliffe EB, Hutchison WD, Cancelado RE (eds) Integrated pest management. Concepts, tactics, strategies and case studies. Cambridge University Press, Cambridge, pp 151-162

Gaudin R, Celette F, Gary C (2010) Contribution of runoff to incomplete off season soil water refilling in a Mediterranean vineyard. Agric Wat Manag 97:1534-1540. doi:10.1016/j.agwat.2010.05.007

Gianinazzi S, Gollotte A, Binet MN, van Tuinen D, Redecker D, Wipf D (2010) Agroecology: the key role of arbuscular mycorrhizas in ecosystem services. Mycorrhiza. doi:10.1007/s00572-010-0333-3

Gliessman SR (1997) Agroecology: ecological processes in sustainable agriculture. CRC Press, Boca Raton

Gurr GM, Wratten SD (2000) Biological control: measure of success. Springer, Dordrecht

Gurr GM, Wratten SD, Altieri MA (2004) Ecological engineering for pest management. Advances in habitat manipulation for arthropods. CSIRO, Australia

Hartmann A, Schmid M, van Tuinen D, Berg G (2009) Plant-driven selection of microbes. Plant Soil 321:235-257. doi:10.1007/s11104008-9814-y

Hauggaard-Nielsen H, Ambus P, Jensen ES (2001) Interspecific competition, $\mathrm{N}$ use and interference with weeds in pea-barley intercropping. Field Crops Res 70:101-109. doi:10.1016/S03784290(01)00126-5

Hauggaard-Nielsen H, Andersen MK, Jornsgaard B, Jensen ES (2006) Density and relative frequency effects on competitive interactions and resource use in pea-barley intercrops. Field Crops Res 95:256267. doi:10.1016/j.fcr.2005.03.003

Hill SB, MacRae RJ (1995) Conceptual framework for the transition from conventional to sustainable agriculture. J Sust Agric 7:81-87

Hokkanen HMT (1991) Trap cropping in pest management. Annu Rev Entomol 36:119-138. doi:10.1146/annurev.ento.36.1.119

Holland JM (2004) The environmental consequences of adopting conservation tillage in Europe: reviewing the evidence. Agric Ecosyst Environ 103:1-25. doi:10.1016/j.agee.2003.12.018

Huang J, Pray C, Rozelle S (2002) Enhancing the crops to feed the poor. Nature 418:678-684. doi:10.1038/nature01015

INRA, CIRAD (2009) Agrimonde. Scenarios and challenges for feeding the world in 2050. Summary report. Paris, France

Isman MB (2006) Botanical insecticides, deterrents, and repellents in modern agriculture and increasingly regulated world. Annu Rev Entomol 51:45-66. doi:10.1146/annurev.ento.51.110104.151146 
Isman MB (2008) Botanical insecticides: for richer, for poorer. Pest Manag Sci 64:8-11. doi:10.1002/ps.1470

Jackson LE, Pascual U, Hodgkin T (2007) Utilizing and conserving agrobiodiversity in agricultural landscapes. Agric Ecosyst Environ 121:196-210. doi:10.1016/j.agee.2006.12.017

Jensen ES, Peoples MB, Hauggaard-Nielsen H (2010) Faba bean in cropping systems. Field Crops Res 115:203-216. doi:10.1016/j.fcr. 2009.10.008

Justes E, Dorsainvil F, Thiébeau P, Alexandre M (2002) Effect of catch crops on the water budget of the fallow period and the succeeding main crop. Proceedings 7th ESA Congress, Cordoba, Spain, pp 503-504

Khan ZR, Pickett JA (2004) The 'push-pull' strategy for stemborer management: a case study in exploiting biodiversity and chemical ecology. In: Gurr GM, Wratten SD, Altieri MA (eds) Ecological engineering for pest management. Advances in habitat manipulation for arthropods. CSIRO, Australia, pp 155-164

Koocheki A, Nassiri M, Alimoradi L, Ghorbani R (2009) Effect of cropping systems and crop rotations on weeds. Agron Sustain Dev 29:401-408. doi:10.1051/agro/2008061

Köpke U, Nemecek T (2009) Ecological services of faba bean. Field Crops Res 115:217-233

Kromp B (1999) Carabid beetles in sustainable agriculture: a review on pest control efficacy, cultivation impacts and enhancement. Agric Ecosyst Environ 74:187-228. doi:10.1016/S0167-8809(99)00037-7

Kruidhof H, Bastiaans L, Kropff MJ (2008) Ecological weed management by cover cropping: effects on weed growth in autumn and weed establishment in spring. Weed Res 48:492-502. doi:10.1111/j. 1365-3180.2008.00665.x

Latif MA, Mehuys GR, Mackenzie AF, Alli I, Faris MA (1992) Effects of legumes on soil physical quality in a maize crop. Plant Soil 140:1523. doi:10.1007/BF00012802

Le Bissonnais Y, Lecomte V, Cerdan O (2004) Grass strip effects on runoff and soil loss. Agronomie 24:129-136. doi:10.1051/ agro:2004010

Lemaire G, Jeuffroy M-H, Gastal F (2008) Diagnosis tool for plant and crop N status in vegetative stage. Eur J Agron 28:614-624. doi:10. 1016/j.eja.2008.01.005

Li W, Li L, Sun J, Guo T, Zhang F, Bao X, Peng A, Tang C (2005) Effects of intercropping and nitrogen application on nitrate present in the profile of an Orthic anthrosol in northwest China. Agric Ecosyst Environ 105:483-491. doi:10.1016/j.agee.2004.07.008

Lopes CM, Santos TP, Monteiro A, Rodrígues ML, Costa JM, Chaves MM (2011) Combining cover cropping with deficit irrigation in a Mediterranean low vigor vineyard. Sci Hort 129:603-612. doi:10. 1016/j.scienta.2011.04.033

Loreau M (2000) Biodiversity and ecosystem functioning: recent theoretical advances. Oikos 91:3-17. doi:10.1034/j.1600-0706.2000. 910101.x

Malézieux E, Crozat Y, Dupraz C, Laurans M, Makowski D, OzierLafontaine H, Rapidel B, de Tourdonnet S, Valantin-Morison M (2009) Mixing plant species in cropping systems: concepts, tools and models. A review. Agron Sustain Dev 29:43-62. doi:10.1051/ agro:2007057

Malusá E, Sas-Paszt L, Ciesielska J (2012) Technologies for beneficial microorganisms inocula used as biofertilizers. Sci World J. doi:10. 1100/2012/491206

McNeely JA, Scherr SJ (2003) Ecoagriculture. Strategies to feed the world and save biodiversity. Island Press, Washington D.C

Médiène S, Valantin-Morison M, Sarthou J-P, de Tourdonnet S, Gosme M, Bertrand M, Roger-Estrade J, Aubertot J-N, Rusch A, Motisi N, Pelosi C, Doré T (2011) Agroecosystem management and biotic interactions: a review. Agron Sust Dev. doi:10.1007/s13593-011-0009-1

Midmore DJ (1993) Agronomic modification of resource use and intercrop productivity. Field Crops Res 34:357-380. doi:10.1016/03784290(93)90122-4
Millennium Ecosystem Assessment (2005) Ecosystems and human wellbeing: biodiversity synthesis. World Resource Institute, Washington, D.C

Mordue AJ, Nisbet AJ (2000) Azadirachtin from the Neem tree Azadirachta indica: its action against insects. An Soc Entomol Brasil 29:615-632

Nearing MA, Jetten V, Baffaut C, Cerdan O, Couturier A, Hernandez M, Le Bissonnais Y, Nichols MH, Nunes JP, Renschle CS (2005) Modeling response of soil erosion and runoff to changes in precipitation and cover. Catena 61:131-154. doi:10.1016/j.catena.2005. 03.007

Obrycki JJ, Harwood JD, Kring TJ, O'Neil RJ (2009) Aphidophagy by Coccinellidae: application of biological control in agroecosystems. Biol Control 51:244-254. doi:10.1016/j.biocontrol.2009.05.009

Ong CK (1995) The "dark side" of intercropping: manipulation of soil resources. In: Sinoquet H, Cruz P (eds) Ecophysiology of tropical intercropping. INRA, Paris, pp 45-66

Ortas I (2012) The effect of mycorrhizal fungal inoculation on plant yield, nutrient uptake and inoculation effectiveness under long-term field conditions. Field Crops Res 125:35-48. doi:10.1016/j.fcr.2011.08. 005

Östman O, Ekbom B, Bengtsson J (2001) Landscape heterogeneity and farming practice influence biological control. Basic Appl Ecol 2: 365-371. doi:10.1078/1439-1791-00072

Ozier-Lafontaine H, Vercambre G, Tournebize R (1997) Radiation and transpiration partitioning in a maize-sorghum intercrop: test and evaluation of two models. Field Crops Res 49:127-145. doi:10. 1016/S0378-4290(96)01047-7

Ozier-Lafontaine H, Lafolie F, Bruckler L, Tournebize R, Mollier A (1998) Modelling competition for water in intercrops: theory and comparison with field experiments. Plant Soil 204:183-201. doi:10. 1023/A:1004399508452

Pala M, Ryan J, Zhang H, Singh M, Harris HC (2007) Water-use efficiency of wheat-based rotation systems in a Mediterranean environment. Agric Wat Manag 93:136-144. doi:10.1016/j.agwat.2007.07. 001

Peigné J, Ball B, Roger-Estrade J, David C (2007) Is conservation tillage suitable for organic farming? A review. Soil Use Manag 23:129 144. doi:10.1111/j.1475-2743.2006.00082.x

Peigné J, Cannavaciuolo M, Gautronneau Y, Aveline A, Giteau JL, Cluzeau D (2009) Earthworm populations under different tillage systems in organic farming. Soil Tillage Res 104:207-214. doi:10. 1016/j.still.2009.02.011

Pellegrino E, Bedini S, Avio L, Bonari E, Giovannetti M (2011) Field inoculation effectiveness of native and exotic arbuscular mycorrhizal fungi in a Mediterranean agricultural soil. Soil Biol Biochem 43: 367-376. doi:10.1016/j.soilbio.2010.11.002

Pelosi C, Bertrand M, Roger-Estrade J (2009) Earthworm community in conventional, organic and direct seeding with living mulch cropping systems. Agron Sustain Dev 29:287-295. doi:10.1051/agro/ 2008069

Perfecto I, Vandermeer J (2010) The agroecological matrix as alternative to the land-sparing/agriculture intensification model. Proc Natl Acad Sci 107:5786-5791. doi:10.1073/pnas.0905455107

Phipps RH, Park JR (2002) Environmental benefits of genetically modified crops: global and European perspectives on their ability to reduce pesticide use. J Anim Feed Sci 11:1-18

Prasifka JR, Hellmich RL, Weiss MJ (2009) Role of biotechnology in sustainable agriculture. In: Radcliffe EB, Hutchison WD, Cancelado RE (eds) Integrated pest management. Concepts, tactics, strategies and case studies. Cambridge University Press, Cambridge, pp 260-272

Pretty JN, Morison JIL, Hine RE (2003) Reducing food poverty by increasing agricultural sustainability in developing countries. Agric Ecosyst Environ 95:217-234. doi:10.1016/S0167-8809(02)00087-7

Ratnadass A, Fernandes P, Avelino J, Habib R (2012) Plant species diversity for sustainable management of crop pests and diseases in 
agroecosystems: a review. Agro Sust Dev 32:273-303. doi:10.1007/ s13593-011-0022-4

Regnault-Roger C, Philogène BJR (2008) Past and current prospects for the use of botanicals and plant allelochemicals in integrated pest management. Pharm Biol 46:41-52. doi:10.1080/13880200701729794

Richardson AE, Barea JM, McNeill AM, Prigent-Combaret C (2009) Acquisition of phosphorus and nitrogen in the rhizosphere and plant growth promotion by microorganisms. Plant Soil 321:305-339. doi: 10.1007/s11104-009-9895-2

Ricketts TH, Regetz J, Steffan-Dewenter I, Cunningham SA, Kremen C, Bogdanski A, Gemmill-Herren B, Greenleaf SS, Klein AM, Mayfield MM, Morandin LA, Ochieng A, Viana BF (2008) Landscape effects on crop pollination services: are there general patterns? Ecol Lett 11: 499-515. doi:10.1111/j.1461-0248.2008.01157.x

Rigueiro-Rodrígues A, McAdam J, Mosquera-Losada MR (2009) Agroforestry in Europe. Current status and future prospects. Springer, Dordrecht

Ryan PR, Dessaux Y, Thomashow LS, Weller DM (2009) Rhizosphere engineering and management for sustainable agriculture. Plant Soil 321:363-383. doi:10.1007/s11104-009-0001-6

Salado-Navarro LR, Sinclair TR (2009) Crop rotations in Argentina: analysis of water balance and yield using crop models. Agric Syst 102:11-16. doi:10.1016/j.agsy.2009.06.004

Sanchez JE, Harwood RR, Willson TC, Kizilkaya K, Smeenk J, Parker E, Paul EA, Knezek BD, Robertson GP (2004) Managing soil carbon and nitrogen for productivity and environmental quality. Agron J 96: 769-775

Schmidt O, Clements RO, Donaldson G (2003) Why do cereal-legume intercrops support large earthworm populations? App Soil Ecol 22: 181-190. doi:10.1016/S0929-1393(02)00131-2

Schmidtke K, Neumann A, Hof C, Rauber R (2004) Soil and atmospheric nitrogen uptake by lentil (Lens culinaris Medik.) and barley (Hordeum vulgare ssp. nudum L.) as monocrops and intercrops. Field Crops Res 87:245-256. doi:10.1016/j.fcr.2003.11.006

Scholberg JMS, Dogliotti S, Leoni C, Cherr CM, Zotarelli L, Rossing WAH (2010) Cover crops for sustainable agrosystems in the Americas. In: Lichtfouse E (ed) Genetic engineering, biofertilisation, soil quality and organic farming. Springer, Dordrecht, pp $23-58$

Scholte K (2000a) Screening of non-tuber bearing Solanaceae for resistance to and induction of juvenile hatch of potato cyst nematodes and their potential for trap cropping. Ann Appl Biol 136:239-246. doi:10.1111/j.1744-7348.2000.tb00030.x

Scholte K (2000b) Growth and development of plants with potential for use as trap crops for potato cyst nematodes and their effects on the number of juveniles in cysts. Ann Appl Biol 137:31-42. doi:10. 1111/j.1744-7348.2000.tb00054.x

Scholte K, Vos J (2000) Effects of potential trap crops and planting date on soil infestation with potato cyst nematodes and root-knot nematodes. Ann Appl Biol 137:153-164. doi:10.1111/j.1744-7348.2000. tb00047.x

Shelton AM, Badenes-Perez FR (2006) Concepts and applications of trap cropping in pest management. Annu Rev Entomol 51:285-308. doi: 10.1146/annurev.ento.51.110104.150959

Shepherd MA, Harrison R, Webb J (2002) Managing soil organic matter: implications for soil structure on organic farms. Soil Use Manag 18: 284-292. doi:10.1079/SUM2002134

Singh JS, Pandey VC, Singh DP (2011) Efficient soil microorganisms: a new dimension for sustainable agriculture and environmental development. Agric Ecosyst Environ 140:339-353. doi:10.1016/j.agee. 2011.01.017

Sinoquet H, Caldwell RM (1995) Estimation of light capture and partitioning in intercropping systems. In: Sinoquet H, Cruz P (eds) Ecophysiology of tropical intercropping. INRA, Paris, pp 79-98

Sinzogan AAC, Kossou DK, Atachi P, van Huis A (2006) Participatory evaluation of synthetic and botanical pesticide mixtures for cotton bollworm control. Int J Trop Ins Sci 26:246-255. doi:10.1017/ S1742758406415691

Soane BD, Ball BC, Arvidsson J, Basch G, Moreno F, Roger-Estrade J (2012) No-till in northern, western and south-western Europe: a review of problems and opportunities for crop production and the environment. Soil Till Res 118:66-87. doi:10.1016/j.still.2011.10.015

Srinivasan A (2006) Handbook of precision agriculture: principles and applications. Haworth Press, New York, USA

Steenwerth K, Belina KM (2008) Cover crops and cultivation: impacts on soil $\mathrm{N}$ dynamics and microbiological function in a Mediterranean vineyard agroecosystem. App Soil Ecol 40:370-380. doi:10.1016/j. apsoil.2008.06.004

Swaminathan MS (2007) Can science and technology feed the world in 2025? Field Crop Res 104:3-9. doi:10.1016/j.fcr.2007.02.004

Tabaglio V, Gavazzi C, Schulz M, Marocco A (2008) Alternative weed control using the allelopathic effect of natural benzoxazinoids from rye mulch. Agron Sustain Dev 28:397-401. doi:10.1051/agro:2008004

Teasdale JR, Coffman CB, Mangum RW (2007) Potential long-term benefits of no-tillage and organic cropping systems for grain production and soil improvement. Agron J 99:1297-1305. doi:10.2134/agronj2006.0362

Thies C, Tscharntke T (1999) Landscape structure and biological control in agroecosystems. Science 285:893-895. doi:10.1126/science.285. 5429.893

Thies C, Steffan-Dewenter I, Tscharntke T (2003) Effects of landscape context on herbivory and parasitism at different spatialscales. Oikos 101:18-25. doi:10.1034/j.1600-0706.2003.12567.x

Tilman D, Cassman KG, Matson PA, Naylor R, Polasky S (2002) Agricultural sustainability and intensive production practices. Nature 418:671-677. doi:10.1038/nature01014

Tilman D, Reich PB, Knops J (2006) Biodiversity and ecosystem stability in a decade-long grassland experiment. Nature 441:629-632. doi: 10.1038/nature 04742

Tscharntke T, Bommarco R, Clough Y, Crist TO, Kleijn D, Rand TA, Tyliankis JM, van Nouhuys S, Vidal S (2007) Conservation biological control and enemy diversity on a landscape scale. Biol Control 43:294-309. doi:10.1016/j.biocontrol.2007.08.006

Turner NC (2004) Agronomic options for improving rainfall-use efficiency of crops in dryland farming systems. J Exp Bot 55:2413-2425. doi:10.1093/jxb/erh154

United Nations (2009) World population prospects: the 2008 revision. Population Division of the Department of Economic and Social Affairs of the United Nations Secretariat. http://esa.un.org/unpp. Accessed March 2011

Uphoff N (2002) Agroecological innovations. Increasing food production with participatory development. Earthsan, London

Uvah III, Coaker TH (1984) Effect of mixed cropping on some insect pests of carrots and onions. Entomol Exp Appl 36:159-167

Van Noordwijk M, Lawson GJ, Soumare A, Groot JJR, Hairiah K (1996) Root distribution of tree and crops: competition and/or complementarity. In: Ong CK, Huxley P (eds) Tree-crop interactions: a physiological approach. CAB Int, Wallingford, pp 319-365

Vandermeer J (1989) The ecology of intercropping. Cambridge University Press, New York

Vandermeer J, van Noordwijk M, Anderson J, Ong C, Perfecto I (1998) Global change and multi-species agroecosystems: concepts and issues. Agric Ecosyst Environ 67:1-22. doi:10.1016/S01678809(97)00150-3

Vandermeer J, Lawrence D, Symstad A, Hobbie S (2002) Effect of biodiversity on ecosystem functioning in managed ecosystems. In: Loreau M, Naeem S, Inchausti P (eds) Biodiversity and ecosystem functioning: synthesis and perspectives. Oxford University Press, Oxford, pp 221-235

Verbruggen E, van der Heijden MGA, Rillig MC, Kiers ET (2013) Mycorrhizal fungal establishment in agricultural soils: factors determining inoculation success. New Phytol 197:1104-1109. doi:10. $1111 / j .1469-8137.2012 .04348 . x$ 
Vessey JK (2003) Plant growth promoting rhizobacteria as biofertilizers. Plant Soil 255:571-586. doi:10.1023/A:1026037216893

Vian JF, Peigne J, Chaussod R, Roger-Estrade J (2009) Effects of four tillage systems on soil structure and soil microbial biomass in organic farming. Soil Use Manag 25:1-10. doi:10.1111/j.1475-2743.2008.00176.x

Watson CA, Atkinson D, Gosling P, Jackson LR, Rayns FW (2002) Managing soil fertility in organic farming systems. Soil Use Manag 18:239-247. doi:10.1079/SUM2002131

Weston LA (1996) Utilization of allelopathy for weed management in agroecosystems. Agron J 88:860-866

Wezel A, Rath T (2002) Resource conservation strategies in agroecosystems of semi-arid West Africa. J Arid Env 51:383-400. doi: 10.1006/jare.2001.0968

Wezel A, Bellon S, Doré T, Francis C, Vallod D, David C (2009) Agroecology as a science, a movement or a practice. A review. Agron Sustain Dev 29:503-515. doi:10.1051/agro/2009004
Whipps JM (2001) Microbial interactions and biocontrol in the rhizosphere. J Expe Bot 52:487-511

Willey RW (1990) Resource use in intercropping systems. Agric Wat Manag 17:215-231. doi:10.1016/0378-3774(90)90069-B

With JE, King AW (1999) Extinction thresholds for species in fractal landscapes. Conserv Biol 13:314-326. doi:10.1046/j.1523-1739. 1999.013002314.x

Wojtkowski PA (2006) Introduction to agroecology. Principles and practices. Haworth Press, Binghampton

Wu J, Huang D, Teng W, Sardo V (2010) Grass hedges to reduce overland flow and soil erosion. Agron Sustain Dev 30:481-485. doi:10.1051/agro/2009037

Zebarth BJ, Drury CF, Tremblay N, Cambouris AN (2009) Opportunities for improved fertilizer nitrogen management in production of arable crops in eastern Canada: a review. Can J Soil Sci 89:113-132 